\title{
MELCOR 1.8.2 Analyses in Support of ITER's RPrS
}

\author{
Brad J. Merrill
}

January 2008

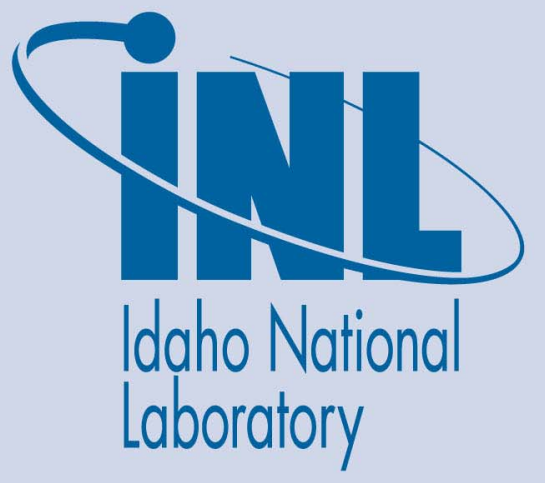

The INL is a U.S. Department of Energy National Laboratory operated by Battelle Energy Alliance 
INL/EXT-08-13668

\section{MELCOR 1.8.2 Analyses in Support of ITER's RPrS}

Brad J. Merrill

January 2008

\section{Idaho National Laboratory \\ Idaho Falls, Idaho 83415}

Prepared for the

U.S. Department of Energy

Office of Science

Under DOE Idaho Operations Office

Contract DE-AC07-05ID14517 


\title{
MELCOR 1.8.2 Analyses in Support of ITER's RPrS
}

\author{
INL/EXT-08-13668
}

January 2008

Approved by

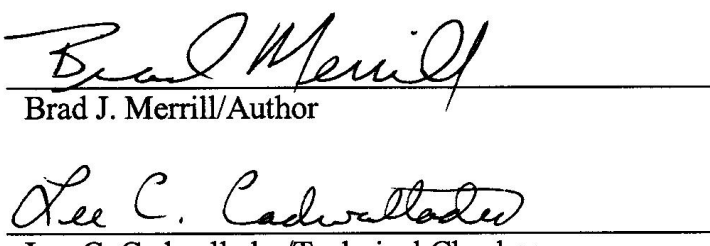

Lee C. Cadwallader/Technical Checker

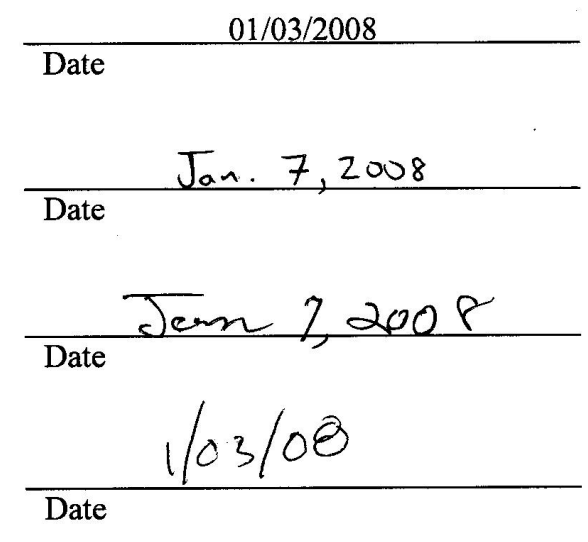

Richard L. Moore/Peer Reviewer

Phil Sharpe/Approver/Manager ore

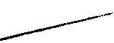




\section{ABSTRACT}

The International Thermonuclear Experimental Reactor (ITER) Program is performing accident analyses for ITER's "Rapport Préliminaire de Sûreté" (Report Preliminary on Safety - RPrS) with a modified version of the MELCOR 1.8.2 code. The RPrS is an ITER safety document required in the ITER licensing process to obtain a "Décret Autorisation de Construction" (a Decree Authorizing Construction - DAC) for the ITER device. This report documents the accident analyses performed by the US with the MELCOR 1.8.2 code in support of the ITER RPrS effort. This work was funded through an ITER Task Agreement for MELCOR Quality Assurance and Safety Analyses. Under this agreement, the US was tasked with performing analyses for three accident scenarios in the ITER facility. Contained within the text of this report are discussions that identify the cause of these accidents, descriptions of how these accidents are likely to proceed, the method used to analyze the consequences of these accidents, and discussions of the transient thermal hydraulic and radiological release results for these accidents. 


\section{ACRONYMS}

\begin{tabular}{|c|c|}
\hline AAS & Accident Analysis Specification \\
\hline $\mathrm{ACP}$ & Activated Corrosion Products \\
\hline BDBA & Beyond DBA \\
\hline $\mathrm{CS}$ & Central Solenoid \\
\hline DAC & Decree Authorizing Construction \\
\hline DBA & Design Basis Accident \\
\hline DT & Drain Tank \\
\hline $\mathrm{EC}$ & Enhanced Condensation \\
\hline EVITA & European Vacuum Impingement Test Apparatus \\
\hline FPTS & Fast Plasma Termination System \\
\hline $\mathrm{FW} / \mathrm{BL}$ & First Wall/Blanket \\
\hline GSSR & Generic Site Safety Report \\
\hline g-T & Grams of Tritium \\
\hline HTO & Tritiated Water $\left(\mathrm{H}_{2} \mathrm{O}\right)$ \\
\hline HVAC & Heating Ventilation Air Conditioning \\
\hline IDM & ITER Document Management \\
\hline INL & Idaho National Laboratory \\
\hline IO & International Organization \\
\hline ITER & International Thermonuclear Experimental Reactor \\
\hline N-VDS & Normal VDS \\
\hline $\mathrm{PF}$ & Poloidal Field \\
\hline PHTS & Primary Heat Transport System \\
\hline
\end{tabular}




$\begin{array}{ll}\text { PIE } & \text { Postulated Initiating Event } \\ \text { RPrS } & \text { Report Preliminary on Safety } \\ \text { SADL } & \text { Safety Analysis Data List } \\ \text { ST-VS } & \text { Suppression Tank-Vent System } \\ \text { S-VDS } & \text { Safety VDS } \\ \text { TCWS } & \text { Tokamak Cooling Water System } \\ \text { TF } & \text { Toroidal Field } \\ \text { VV } & \text { Vacuum Vessel } \\ \text { VDS } & \text { Ventilation Detritiation System } \\ \text { VVPSS } & \text { Vacuum Vessel Pressure Suppression System }\end{array}$





\section{CONTENTS}

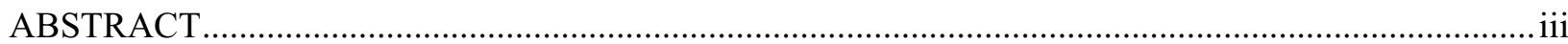

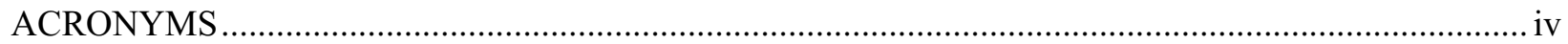

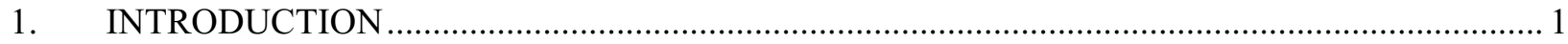

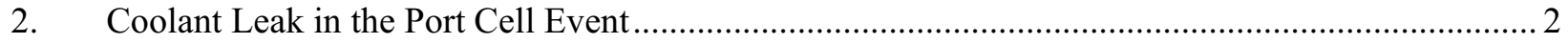

2.1 Identification of Causes and Accident Description ...................................................... 2

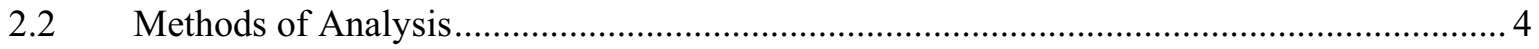

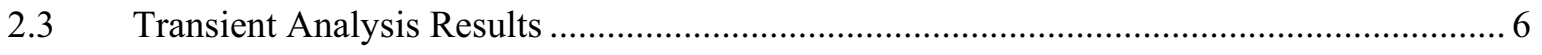

$2.4 \quad$ Transient Analysis Results for the Parameter Studies .................................................... 7

2.5 Radiological Releases for Base Case Scenario.......................................................... 8

2.6 Evaluation of Parameter Study Radiological Release ................................................ 10

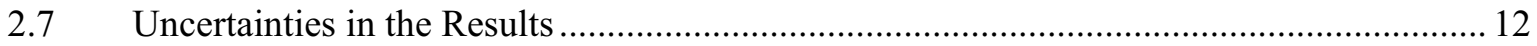

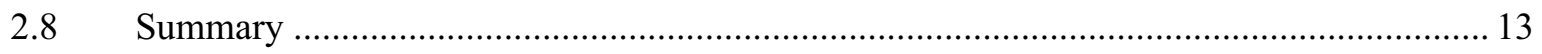

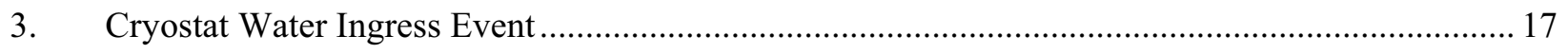

3.1 Identification of Causes and Accident Description .................................................. 17

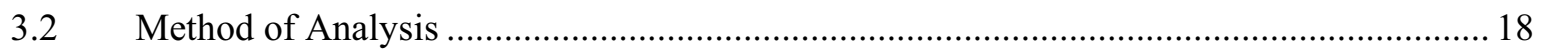

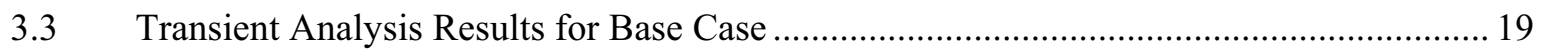

3.4 Transient Analysis Results for Parameter Studies....................................................... 20

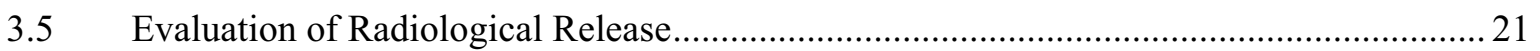

3.6 Evaluation of Parameter Study Radiological Release ..................................................... 21

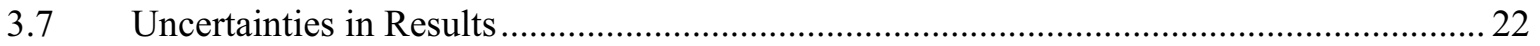

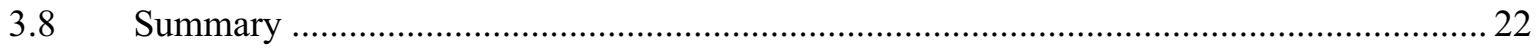

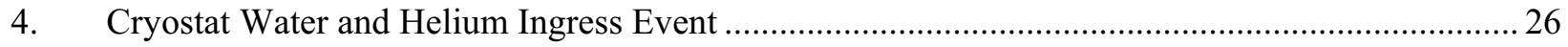

4.1 Identification of Causes and Accident Description ...................................................... 26

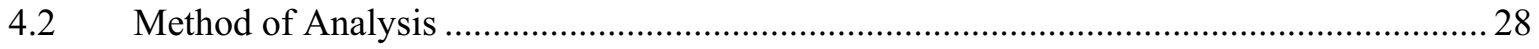

4.3 Transient Analysis Results for Base Case …................................................................. 29 
4.4 Transient Analysis Results for the Parameter Study ................................................ 30

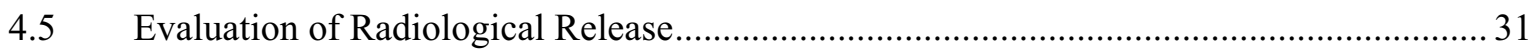

4.6 Evaluation of Parameter Study Radiological Release ................................................. 32

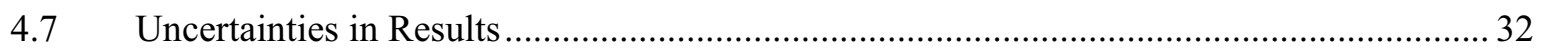

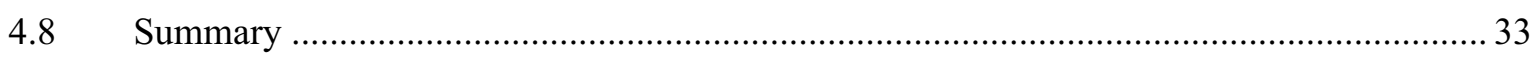

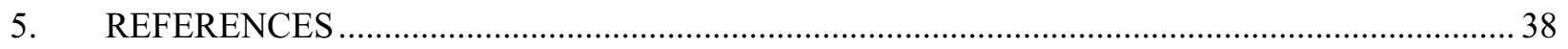

\section{FIGURES}

1. Time Transient of Physical Quantities for the Port Cell Leak Event following a FW/BL PHTS $66 \mathrm{~mm}$ pipe break in the Port Cell and a FW break into the VV..... 14

2. Time Transient of Physical Quantities for the Port Cell Leak Event following a FW/BL PHTS 66 mm pipe break during normal and baking PHTS conditions.

3. Time Transient of Radioactive Quantities for the Port Cell Leak Event following a FW/BL PHTS 66 $\mathrm{mm}$ pipe break during normal PHTS conditions

4. Time Transient of Physical Quantities for the Cryostat Water Ingress Event following a FW/BL PHTS break of a single $66 \mathrm{~mm}$ pipe

5. Time Transient of Physical Quantities for Parameter Studies for the Cryostat Water Ingress Event

6. Time Transient of Aerosol Quantities for the Cryostat Water Ingress Event..

7. Time Transient of Physical Quantities for the Cryostat Water Helium Ingress Event.

8. Time Transient of Cryostat Pressures for the Cryostat Water Helium Ingress Event When Enhanced Steam Condensation is Considered

9. Time Transient of Physical Quantities for the Parameter Study for the Cryostat Water Helium Ingress Event. 36

10. Time Transient of Radioactive Quantities for the Cryostat Water Helium Ingress Event 37

\section{TABLES}

Table 2-1. Time Sequence of Coolant Leak in Port Cell 4

Table 2-2. Parameters and Initial Conditions Used in Coolant Leak in the Port Cell Analysis 5 
Table 2-3. Mobilized Inventory, Transport and Release to Environment in Coolant Leak into Port Cell Event.

Table 2-4. Mobilized Inventory, Transport and Release to Environment for Coolant Leak into Port Cell Event Parameter Cases

Table 3-1. Time Sequence of Events for Cryostat Water Ingress ........................................................ 18

Table 3-2. Parameters and Initial Conditions Used in Cryostat Water Ingress Analysis ......................... 19

Table 4-1. Time Sequence of Events for Cryostat Water and Helium Ingress ...................................... 27

Table 4-2. Parameters and Initial Conditions for Cryostat Water and Helium Ingress Analysis............... 28

Table 4-3. Mobilized Inventory, Transport and Release to Environment in Cryostat Water and Helium

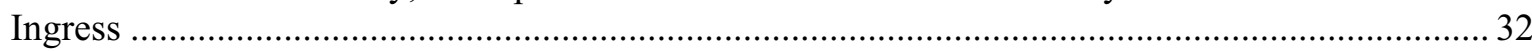




\section{MELCOR 1.8.2 Analyses in Support of ITER's RPrS}

\section{INTRODUCTION}

The International Thermonuclear Experimental Reactor (ITER) Program is performing accident analyses for ITER's "Rapport Préliminaire de Sûreté" (Report Preliminary on Safety $\mathrm{RPrS}$ ) with a modified version of the MELCOR 1.8.2 code [Moo07]. The RPrS is an ITER safety document required in the ITER licensing process to obtain a "Décret Autorisation de Construction" (a Decree Authorizing Construction - DAC) for the ITER device [TAY03]. This report documents the accident analyses performed by the US with the MELCOR 1.8.2 code in support of the ITER RPrS. This work was funded through an ITER Task Agreement for MELCOR Quality Assurance and Safety Analyses [Sau07]. Under this agreement, the US was tasked with performing analyses for three accidents:

1) A coolant leak from ITER first wall $(\mathrm{FW}) /$ blanket $(\mathrm{BL})$ primary heat transport system (PHTS) in the port cell of the ITER confinement building,

2) Ingress of water from ITER's FW/BL PHTS into the ITER cryostat, and

3) Ingress of water from ITER's FW/BL PHTS and helium ITER's toroidal field (TF) magnets into the cryostat of the ITER device.

The following sections present the results obtained for these accidents in ITER. The format for the presentation of these results follows that of [GSSR04] as requested by the ITER International Organization (IO), and will be that adopted for the ITER's Accident Analysis Report, when it is published. Accordingly, each of the following three sections will:

1) Identify the causes of the accident and describe how the accident proceeds,

2) Present the method used in analyzing the accident,

3) Describe the transient analysis results for the base accident case,

4) Describe the transient analysis results for any parameter studies for this accident,

5) Present an evaluation of radiological releases,

6) Present an evaluation of parameter study radiological releases,

7) Discuss uncertainties in obtained results, and

8) Close with a results summary

for the three accidents identified above. 


\section{Coolant Leak in the Port Cell Event}

This accident was chosen for consideration in the ITER RPrS as a design basis accident (DBA) because it challenges the integrity of the port cell of the ITER confinement building and opens a pathway, by way of the FW/BL PHTS, from the interior of the VV into the ITER confinement building. Consequently, a bypass occurs of the primary confinement boundary of ITER (e.g. the VV) so that during this accident scenario radioactive materials within the VV could possibly be mobilized inside the ITER confinement building and subsequently released to the environment as a result of confinement building pressurization. The following subsections of this report section give the details surrounding this event, the assumptions used to model and analyze this accident, and the predicted consequences to ITER and the radioactive releases to the environment.

\subsection{Identification of Causes and Accident Description}

The postulated initiating event (PIE) is a double ended pipe rupture of the largest diameter $(\mathrm{ID}=66 \mathrm{~mm}$ ) cooling pipe of the first wall/blanket shield primary heat transport system (FW/BL PHTS) inside of the ITER confinement building port cell. This event will discharge coolant from an ITER PHTS pipe that has the highest coolant enthalpy during full power operation (500 MW of fusion power), directly into the port cell creating a possible overpressure condition in this cell. The loss of coolant from the FW/BL PHTS will result in a low liquid level in the pressurizer of this cooling system, which will actuate the Fast Plasma Termination System (FPTS) and terminate the plasma burn. It is assumed that this plasma burn termination will cause a disruption that fails the FW of ITER, allowing high pressure coolant from the FW/BL PHTS to discharge into the vacuum vessel (VV) creating a possible overpressure condition in this structure. Because of these two failures in the FW/BL PHTS, a pathway will exist for the radioactivity inside of the ITER VV to move from the VV into the confinement building and once inside of the confinement building lost to the environment by building leakage or venting.

This accident is assumed to occur coincident with a 32 hour loss of offsite power, aggravated by a 1 hour station blackout due to an assumed loss of class-III emergency AC generator power [AAS07]. The result will be a loss of forced convection cooling as pumps within the intact $\mathrm{FW} / \mathrm{BL}$, divertor, and the VV cooling loops coast to a stop in $32 \mathrm{~s}$ after the loss of pump power [SAD07]. The VV cooling loop will transition into the natural convection heat transfer mode upon loss of pumping power and remove the decay heat from the VV in-vessel components by this heat transfer mode [SAD07]. Normally the class-III power is available in $30 \mathrm{~s}$. Because some safety systems, such as the PHTS afterheat removal pumps and the Ventilation Detritiation System (VDS), are powered during emergency conditions by class-III power, the loss of this power (a complete station blackout) for an hour is considered to be an aggravating condition for this accident. The consequences of this accident were evaluated for both a normal class-III power startup and a 1 hour delayed class-III power startup. Because there was very little difference in the thermal hydraulic results between these scenarios, and the releases for the aggravated scenario were less than $\sim 10 \%$ greater than the base case, only the accident scenarios assuming a 1 hour station blackout are presented in this report. 
The coolant leak into port cell event was selected as one of the accident events because it demonstrates the design approach to minimizing the consequences of pressurization events in ITER, both for the VV and the confinement building. The objective is to show that accidental overpressure in the port cell will be safely mitigated and that the radioactive releases are adequately confined; that is, that the accidental releases are below the ITER Accident Release Guidelines.

Table 2-1 lists a time sequence for this reference accident.

Listed below are the safety relevant systems for this accident:

- FPTS intervention: three seconds after detection of the fault condition; set points for FPTS intervention are:

- PHTS vault pressure differential to neighboring rooms $>5 \mathrm{kPa}$;

- FW/BL PHTS coolant flow $<80 \%$ of its nominal value;

- Maximum coolant outlet temperature $>170^{\circ} \mathrm{C}$;

- Low water level in pressurizer $<1.3 \mathrm{~cm}$.

- $\mathrm{VV}$ design pressure is $200 \mathrm{kPa}$ ( $1^{\text {st }}$ radioactive confinement barrier);

- Suppression tank-vent system (ST-VS) serving the ST will start after detection of pressurization or air ingress in the VV; the time for start up is 3 minutes after the signal of pressure. The processing rate is $150 \mathrm{~m}^{3}-\mathrm{STP} /$ hour.

- The ST-VS exhaust is routed through the normal-vent detritiation system (NVDS). The ST-VS + N-VDS removal efficiency for tritium is $99 \%$ and for dust is $99.9 \%$.

- Two large relief ducts lead from NBI ports to the inlet of the ST distributor open at a pressure of $150 \mathrm{kPa}$ in the plasma chamber;

- A small bleed line connecting the VV with the ST opens at 90 $\mathrm{kPa}$. Its routing is the same as the two large relief ducts.

- The plasma chamber is returned to below atmospheric pressure within $24 \mathrm{~h}$;

- Port cell design pressure is $160 \mathrm{kPa}$;

- Relief path to Tokamak Cooling Water System (TCWS) vault through a $0.2 \mathrm{~m}^{2}$ relief panel between port cell and pipe shaft that initially opens at a pressure differential of $20 \mathrm{kPa}$, remains fully open as long as the pressure differential is greater than $21 \mathrm{kPa}$, and will re-close if it is less than $20 \mathrm{kPa}$;

- Vacuum breaker of $\sim 0.04 \mathrm{~m}^{2}$ between the gallery and port cell opens at a pressure differential of $5 \mathrm{kPa}$, is fully open at $10 \mathrm{kPa}$ and re-closes at $5 \mathrm{kPa}$.

- TCWS vault design pressure is $200 \mathrm{kPa}$ ( $2^{\text {nd }}$ radioactive confinement barrier);

- TCWS vault is assumed to be isolated within 30 seconds after detection of an overpressure of $5 \mathrm{kPa}$;

- Coolers in the TCWS vault restore sub-atmospheric pressure within 24 hours, from up to $200 \mathrm{kPa}$.

- The leak rate for the TCWS vault is 100 volume \%/day at design pressure, and scales with the square root of pressure differential.

- The TCWS vault atmosphere is exhausted in normal operation to the environment through the N-VDS (dust + Activated Corrosion Products $(\mathrm{ACP})$ filter efficiency $=99.9 \%$, tritium efficiency $=$ $99 \%$;

- Once the TCWS vault pressure reaches near sub-atmospheric conditions by vault cooler operation, the N-VDS (or safety-vent detritiation system S-VDS) will start to recover the vault to allow access and maintain the pressure sub-atmospheric. 
The objectives of this accident analysis are to demonstrate that the:

- Accidental overpressure will be safely accommodated by the port cell and vault (maximum port cell and vault pressures are $160 \mathrm{kPa}$ and $200 \mathrm{kPa}$ )

- Demonstrate that the VV hydrogen production is less than $4 \mathrm{~kg}$

- Show that radioactive releases are adequately confined (radioactive releases are less than ITER accident release limits)

To examine the safety margins associated with this event, two additional parameter studies were analyzed. These parameter studies examine the same PIE but do so when the ITER device is at baking conditions, resulting in a FW/BL PHTS system temperature of $250{ }^{\circ} \mathrm{C}$. The difference between these two parameter studies is that the first takes credit for the actuation of a port cell FW/BL PHTS bypass system, within $60 \mathrm{~s}$ of a $5 \mathrm{kPa}$ pressure increase in the port cell, and the second parameter study does not. In both cases the port cell will be pressurized up to higher levels, but during baking conditions there is no plasma, so a plasma disruption will not occur. As a consequence, without a plasma disruption damaging the ITER FW there is no possibility of mobilizing the radioactive material within the VV and transporting it into the port cell.

Table 2-1. Time Sequence of Coolant Leak in Port Cell

\begin{tabular}{|l|l|}
\hline Event Sequence & Time \\
\hline Failure of the FW/BL loop pipe in port cell (ex-vessel break) & $0 \mathrm{~s}$ \\
\hline Maximum ex-vessel break flow rate $(\sim 98 \mathrm{~kg} / \mathrm{s})$ & $\sim 0.1 \mathrm{~s}$ \\
\hline FPTS terminates plasma burn, failure of FW (in-vessel break) & $3 \mathrm{~s}$ \\
\hline Maximum in-vessel break flow rate $(\sim 78 \mathrm{~kg} / \mathrm{s})$ & $\sim 3 \mathrm{~s}$ \\
\hline Port cell relief panel opens at set point cell pressure $(120 \mathrm{kPa})$ & $\sim 5 \mathrm{~s}$ \\
\hline Port cell bypass valves actuates & $60 \mathrm{~s}$ \\
\hline Bleed lines to suppression tank $(\mathrm{ST})$ open & $\sim 88 \mathrm{~s}$ \\
\hline Maximum VV pressure $(98 \mathrm{kPa})$ & $\sim 98 \mathrm{~s}$ \\
\hline FW/BL PHTS drops below $100 \mathrm{kPa}$ & $\sim 260 \mathrm{~s}$ \\
\hline In-vessel break flow rate drops below $0.5 \mathrm{~kg} / \mathrm{s}$ & $\sim 1.8$ hours \\
\hline
\end{tabular}

\subsection{Methods of Analysis}

A modified version of the MELCOR code [Moo07a] was used to calculate the resulting coolant flow, pressures and temperatures within the damaged FW/BL-PHTS, VV, VVPSS, port cell, pipe chase, and TCWS vault. MELCOR was also used to calculate structure temperatures of VV in-vessel components. The MELCOR input deck used for this analysis was that developed by [Top07], which also contains a representation of the three FW/BL cooling systems and internal VV components, the divertor cooling system and internal VV components, and the VV cooling system and VV walls. Nuclear heating was included for the internal VV components both during plasma operation and decay heat, plus the surface heating to the VV internal components due to plasma radiant heat and particle losses. A detailed description of this model can be found in [Top07]. The input decks used in this study were obtained from the ITER Document Management (IDM) system and had the designation of:

Coolant_Leak_Port_ITER_D_276W3F_v2_4.inp (FW/BL PHTS loop break when at normal operating conditions), and Coolant_LeakPortC_ITER_D_276W2X_v2_4.inp (FW/BL PHTS loop break when at baking conditions). These input decks, with minor revisions identified by [Moo07b], were verified to conform to both the [SAD07] and [AAS07] by [Moo07b]. Table 2-2 
lists the major assumptions used in this analysis. All thermal properties for these components extend down to cryogenic temperatures for this analysis [SAD07].

Table 2-2. Parameters and Initial Conditions Used in Coolant Leak in the Port Cell Analysis

\begin{tabular}{|c|c|}
\hline Parameter & Value \\
\hline Break size & FW/BL cooling loop pipe diameter: $66 \mathrm{~mm}$ \\
\hline Coolant temperature of FW/BL PHTS [Tin/Tout] & $100 / 148^{\circ} \mathrm{C}$ \\
\hline FW/BL PHTS coolant inventory/loop & $130 \mathrm{~m}^{3}$ \\
\hline 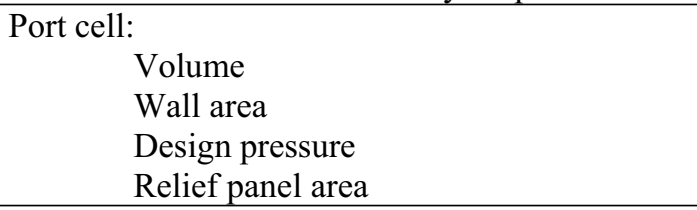 & $\begin{array}{l}200 \mathrm{~m}^{3} \\
240 \mathrm{~m}^{2} \\
160 \mathrm{kPa} \\
\left.0.2 \mathrm{~m}^{2} \text { (set point pressure differential } 20 \mathrm{kPa}\right)\end{array}$ \\
\hline $\begin{array}{l}\text { TCWS vault } \\
\text { Volume } \\
\text { Wall and ceiling/floor areas } \\
\text { Design pressure } \\
\text { Coolers } \\
\text { Leak rate }\end{array}$ & $\begin{array}{l}23,223 \mathrm{~m}^{3} \\
3,400 \mathrm{~m}^{2}, 2,300 \mathrm{~m}^{2} \\
200 \mathrm{kPa} \\
1 \mathrm{MW} \text { when vault pressure exceeds } 101 \mathrm{kPa} \\
100 \% \text { volume/day at design pressure. Linear function } \\
\text { in the delta } \mathrm{P} \text { range between }-0.3 \text { and }+0.3 \mathrm{kPa} \text {, } \\
\text { beyond this range the leak rate scales with the square } \\
\text { root of the pressure differential }\end{array}$ \\
\hline $\begin{array}{l}\text { TCWS vault N-VDS } \\
\text { Set point for actuating } \\
\text { Processing rate } \\
\text { Filtering efficiencies }\end{array}$ & $\begin{array}{l}>0.17 \mathrm{~g}-\mathrm{T} / \mathrm{m}^{3} \text { in room (if power is available) } \\
325 \mathrm{~m}^{3} / \mathrm{hr} \\
\text { HTO detritiation, (initially a reduced efficiency of } 95 \% \\
\text { and full efficiency of } 99 \% \text { in } 30 \mathrm{~min} \text { ) } 99.9 \% \text { for dust }\end{array}$ \\
\hline $\begin{array}{l}\text { Break sizes } \\
\text { FW/BL } 66 \mathrm{~mm} \text { diameter pipe } \\
10 \mathrm{FW} \text { cooling tubes }\end{array}$ & $\begin{array}{l}0.00664 \mathrm{~m}^{2} \\
0.00157 \mathrm{~m}^{2}\end{array}$ \\
\hline Fusion nominal power & $500 \mathrm{MW}$ \\
\hline $\begin{array}{l}\text { FPTS } \\
\text { Set point for intervention } \\
\text { Intervention time delay }\end{array}$ & $\begin{array}{l}\text { FW/BL PHTS coolant flow at } 80 \% \text { of its nominal value } \\
3 \mathrm{~s}\end{array}$ \\
\hline VV free volume & $1350 \mathrm{~m}^{3}$ \\
\hline Drain tank & $\begin{array}{l}\text { Volume }=400 \mathrm{~m}^{3} \text {, water temperature and pressure } 30 \\
{ }^{\circ} \mathrm{C} \text { and } 4.2 \mathrm{kPa}\end{array}$ \\
\hline VVPSS & $\begin{array}{l}\text { Suppression tank }\left(\text { volume }=1200 \mathrm{~m}^{3}\right) ; \text { pool volume }= \\
675 \mathrm{~m}^{3} \text {; water temperature and pressure }=30{ }^{\circ} \mathrm{C} \text { and } \\
4.2 \mathrm{kPa}\end{array}$ \\
\hline Bleed line & To VVPSS $0.05 \mathrm{~m}^{2}, 10 \mathrm{~m}$ length \\
\hline Relief pipe with 2 rupture disks & To VVPSS $1.2 \mathrm{~m}$ diameter, $76 \mathrm{~m}$ length \\
\hline Pressure to open bleed lines & $90 \mathrm{kPa}$ in $\mathrm{VV}$ \\
\hline Pressure to open rupture disks & $150 \mathrm{kPa}$ in $\mathrm{VV}$ \\
\hline ST-VS processing flow rate & $150 \mathrm{~m}^{3}-\mathrm{STP} /$ hour \\
\hline
\end{tabular}




\subsection{Transient Analysis Results}

The wave forms shown in Figure 1 for this accident are:

- FW/BL pipe, Port Cell, and Vault pressures;

- FW cooling pipe and VV pressures;

- Ex-vessel and In-vessel break flow rates;

- Integrated mass flow into the Suppression Tank and Drain Tank

The port cell pressure reaches the relief panel actuation pressure within seconds. Once the spring loaded port cell relief panel opens, the pressure in this cell is maintained at $120 \mathrm{kPa}$ until the port cell bypass valves actuate, which is $60 \mathrm{~s}$ after receiving a high port cell pressure signal (set point pressure $105 \mathrm{kPa}$ ). After the FW/BL PHTS pipes leading into the port cell have been isolated, the flow into the port cell from the break begins to drop, and because the port cell pressurization source is this flow then the port cell pressure will also drop, going below $100 \mathrm{kPa}$ by $250 \mathrm{~s}$. The reason MELCOR predicts that port cell pressure will drop below $100 \mathrm{kPa}$ is because the FW/BL PHTS water expelled into the port cell cools by transferring heat to the port cell walls and floor that are at $30{ }^{\circ} \mathrm{C}$ when the event begins. As the temperature of the water decreases, then so does the water vapor pressure (e.g. the port cell pressure). Once the port cell pressure drops below $120 \mathrm{kPa}$, then the port cell relief panel reseats. Reseating of this panel isolates the port cell from the rest of vault in the model, leaving the only way to restore pressure is by in-leakage of air from adjacent rooms into the port cell. The pressure in the bypassed sections of FW/BL PHTS pipes also decreases as the water in these pipes discharges into the port cell, until the pressure in these pipes reaches equilibrium with the port cell once the water inventory of these pipes has been exhausted. The vault experienced only a slight pressurization $(\sim 200 \mathrm{~Pa})$, which stops after the port cell relief panel reseats at $35 \mathrm{~s}$.

The pressure in the VV reaches a maximum value of $93 \mathrm{kPa}$ at $98 \mathrm{~s}$, which is $\sim 10 \mathrm{~s}$ after the bleed line to the ST opens. Once the bleed line opens to the ST, the VV pressure begins to drop because the steam flow rate into the ST through these lines exceeds the water flow rate from the FW break that is expelling water into the VV from the FW/BL PHTS. This trend continues until the water in the FW/BL PHTS has been discharged into the VV and the pressure in the damaged FW pipes reaches equilibrium with the VV at $\sim 18$ hours into the event. When viewed with the results of the first wave form, it can be seen that the pressure in the FW/BL PHTS remains higher than the pressure in either the port cell (until after isolation of the port cell) or VV during this event.

The FW/BL PHTS ex-vessel break in port cell reaches a maximum value of $70 \mathrm{~kg} / \mathrm{s}$, and then quickly drops to $63 \mathrm{~kg} / \mathrm{s}$ at $60 \mathrm{~s}$. The quantity of water lost from the FW/BL PHTS to the port cell through this break is $\sim 4.5$ tonnes. The FW/BL PHTS in-vessel break results in a maximum break mass flow rate of $78 \mathrm{~kg} / \mathrm{s}$, which drops to $18 \mathrm{~kg} / \mathrm{s}$ by $\sim 200 \mathrm{~s}$ where it remains nearly steady for $\sim 1.8$ hours, and then drops to less than $0.6 \mathrm{~kg} / \mathrm{s}$. The quantity of FW/BL PHTS water that enters the VV through this break is $\sim 114$ tonnes, which is $\sim 94 \%$ of the FW/BL PHTS water inventory. The port cell and vault pressure remained well below the design pressures for these enclosures.

The bleed line to the ST opens at $\sim 88 \mathrm{~s}$ (VV pressure actuation), while the line to the drain tank opens 1 hour after the initiation of this event (timed actuation). Of the 113 tonnes of FW/BL PHTS water that enters the VV, $\sim 9$ tonnes vents into the ST tank, and 102 tonnes drains into the drain tank (DT) of the VVPSS by 36 hours. The quantity of hydrogen 
generated from reaction of steam with the graphite and beryllium plasma facing components in the VV was $1.5 \mathrm{~kg}$ for this event, which is well below the $4 \mathrm{~kg}$ ITER hydrogen deflagration limit.

\subsection{Transient Analysis Results for the Parameter Studies}

Two parameter cases were studied for this accident scenario. These parameter studies examine the same PIE but do so when the ITER device is at baking conditions, resulting in a FW/BL PHTS system temperature of $250{ }^{\circ} \mathrm{C}$ and a flow of $\sim 11 \%$ of that at normal operating conditions. The difference between these two parameter studies is that the first takes credit for the actuation of a port cell FW/BL PHTS bypass system, within $60 \mathrm{~s}$ of a $5 \mathrm{kPa}$ pressure increase in the port cell, and second parameter study does not. Wave forms shown in Figure 2 compare the results for these parameter studies with those of the base case scenario. These wave forms are:

- $\quad$ Port cell pressure;

- $\quad$ TCWS vault pressure;

- $\quad$ Break mass flow rate;

- $\quad$ TCWS vault leakage

The port cell pressure for the base case scenario achieved a maximum of $120 \mathrm{kPa}$ once the relief panel opened between the port cell and the pipe chase leading to the TCWS vault. The parameter case at FW/BL PHTS baking conditions and bypass of the port cell (isolation from the FW/BL PHTS system) continues to rise to $\sim 122 \mathrm{kPa}$ at $60 \mathrm{~s}$ when the port cell is bypassed and the break flow into the port cell stops. The port cell pressure for the parameter case at FW/BL PHTS baking conditions and no bypass of the port cell continues to rise until a maximum value of $\sim 132 \mathrm{kPa}$ is reached at $2410 \mathrm{~s}$. At this point, the break flow from the damaged FW/BL PHTS pipe begins to drop as the break flow from the PHTS turns to steam. The relief panel in the port cell reseats at $4800 \mathrm{~s}$, although steam from the damaged PHTS continues to enter the port cell at a very low flow rate over the next eight hours until this system comes into pressure equilibrium with the port cell. After the relief panel reseats, steam condensation on the port cell walls, plus leakage between the port cell and gallery results in the continued pressure decay in the port cell. In all cases examined, the predicted maximum pressure in the port cell remained below the design pressure of the port cell $(160 \mathrm{kPa})$.

The vault pressure reached a maximum of $\sim 112 \mathrm{kPa}$ at $2400 \mathrm{~s}$ for the parameter case at FW/BL PHTS baking conditions and no port cell bypass scenario. This compares to $\sim 102 \mathrm{kPa}$ for the parameter case at FW/BL PHTS baking conditions and with bypass of the port cell scenario, and $\sim 100.2 \mathrm{kPa}$ for the base case scenario. After the port cell is isolated and the relief panel reseats, the vault pressure for the parameter case pressure drops to the vault chiller set point pressure of $101 \mathrm{kPa}$, where it is maintained for the next 10 hours. The slight pressure source for the vault during this scenario is the predicted warming of atmosphere that enters the pipe chase during the early minutes of this parameter case. The vault pressure for the parameter case at FW/BL PHTS baking conditions and no port cell bypass takes $\sim 5$ hours to drop to the chiller set point pressure as the water droplets that entered the atmosphere of the vault and pipe chase evaporate. Beyond this point the chiller maintains the vault pressure at $101 \mathrm{kPa}$ for the next 17 hours, with the pressure source being the same as that for the parameter case at FW/BL PHTS baking conditions and with bypass of the port cell. The vault pressures for the scenarios examined are well below the design pressure for this room $(200 \mathrm{kPa})$. 
The FW/BL PHTS ex-vessel break in port cell for the parameter cases reaches a maximum flow rate value of $\sim 200 \mathrm{~kg} / \mathrm{s}$, compared to $98 \mathrm{~kg} / \mathrm{s}$ for the base case scenario, and then drops to $\sim 30 \mathrm{~kg} / \mathrm{s}$ at $15 \mathrm{~s}$, compared to $63.5 \mathrm{~kg} / \mathrm{s}$ at $\sim 6 \mathrm{~s}$ for the base case scenario. The lower or plateau flow rate for the parameter case once the PHTS damaged piping begins to void $(30 \mathrm{~kg} / \mathrm{s}$ vs. $63.5 \mathrm{~kg} / \mathrm{s})$ is believed to be due to a higher steam quality exiting the break in the parameter cases. This flow rate was maintained in the parameter cases until either the port cell was bypassed or sufficient PHTS water inventory was exhausted to reach a pressure equilibrium with the port cell. The quantity of FW/BL PHTS water that enters the port cell through the damaged pipe was 2.3 tonnes for the parameter case with port cell bypass and 98 tonnes for the parameter case without port cell bypass. This compares to 4.4 tonnes for the base case scenario.

The quantity of mass leaked from the vault to the environment for the parameter case at baking with no bypass of the port cell was predicted to be $\sim 5660 \mathrm{~kg}$, while that quantity leaked for the parameter study with bypass of the port cell was predicted to be $\sim 3860 \mathrm{~kg}$. This compares to only $194 \mathrm{~kg}$ for the base case scenario. Most of the parameter case leakage occurred for the time at which the pressure in the vault was maintained at the chiller set point pressure $(101 \mathrm{kPa})$.

\subsection{Radiological Releases for Base Case Scenario}

In this analysis, the mobilized radioactive materials are activated dust and tritium (as tritiated water -HTO) from within the VV, and HTO and activated corrosion products (ACP) from within the failed FW/BL PHTS cooling loop. According to [SAD07], the quantity of dust mobilized in the $\mathrm{VV}$ as a result of the coolant ingress is $350 \mathrm{~kg}$, and the quantity of tritium mobilized (assumed to be in the form of HTO) is $1 \mathrm{~kg}$. The dust mobilization history coincides with the VV pressurization event (assumed to be constant over $10 \mathrm{~s}$ ), while the tritium mobilization history is $660 \mathrm{~g}$ immediately mobilized, with another $440 \mathrm{~g}$ mobilized over a 6 hour period of time. The maximum tritium concentration of the FW/BL PHTS coolant is 0.005 $\mathrm{g}-\mathrm{T} / \mathrm{m}^{3}$ [SAD07]. The fraction of this HTO that is mobilized into the atmosphere of the VV or port cell is $100 \%$ of the HTO in the PHTS water that spills into these structures. Given the fraction of water spilled from the FW/BL PHTS during this event, the total amount of tritium mobilized is $\sim 0.63 \mathrm{~g}$-T, with $0.605 \mathrm{~g}$-T mobilized inside of the VV and $0.025 \mathrm{~g}$-T mobilized inside of the port cell. The quantity of ACP in a FW/BL PHTS loop is $10 \mathrm{~kg}$ [SAD07]. The fraction of the ACP mobilized into the VV or port cell atmosphere during this event is $1.3 \%$ of the ACP in the water inventory spilled [SAD07]. Given the fraction of FW/BL PHTS water spilled during this event, the total mobilized inventory of ACP is $112.4 \mathrm{~g}$, with $108 \mathrm{~g}$ mobilized inside of the $\mathrm{VV}$ and $4.4 \mathrm{~g}$ mobilized inside of the port cell.

The wave forms shown in Figure 3 are the radiological release results for the base case scenario. These wave forms are:

- $\quad$ Activated dust mass in the VVPSS ST and DT;

- $\quad$ Tritium mass in the ST and DT;

- $\quad$ ACP mass in the ST and DT;

- $\quad \mathrm{ACP}$ and tritium masses in the TCWS vault.

Because the high pressure source in this event is the FW/BL PHTS, the radioactivity mobilized within the VV during this accident will not be transported into the port cell unless 
the pressure in the VV becomes higher than the PHTS. Based on the results of Section 2.3, this condition does not occur for this event. In addition, because the port cell was isolated from the damaged PHTS within $60 \mathrm{~s}$ of the occurrence of the pipe break, the only radioactive inventories released into the port cell during this event are the tritium and ACP associated with the water spill from the PHTS into the port cell. In fact, since the ST-VS was not activated during this event due to the VV pressure not exceeding the ST-VS set point pressure coincident with having class III power available, the remaining mobilized inventories were confined within the VV, VV extensions, or the VVPSS and not released to the environment. The first three wave forms present the portion of these inventories that reside within the ST or DT of the VVPSS after 36 hours of this event. Of the $350 \mathrm{~kg}$ of dust mobilized, $41 \mathrm{~kg}$ is confined within the ST and $103 \mathrm{~kg}$ is confined within the DT. The remaining $206 \mathrm{~kg}$ has been deposited within various regions of the $\mathrm{VV}$ and its extensions. Of the $1000 \mathrm{~g}$ of tritium mobilized, $445 \mathrm{~g}$ is confined within the ST and $528 \mathrm{~g}$ is confined within the DT. The remaining $27 \mathrm{~g}$ is within various regions of the $\mathrm{VV}$ and its extensions. Of the $108.2 \mathrm{~g}$ of ACP mobilized inside of the VV, $52.8 \mathrm{~g}$ resides in the ST and $6.2 \mathrm{~g}$ resides inside of the DT. The remaining $49.2 \mathrm{~g}$ has been deposited within regions of the VV and its extensions.

The radioactivity released in this accident is that mobilized within the port cell, which is $4.4 \mathrm{~g}$ of ACP and $0.025 \mathrm{~g}$-T as HTO. There are three possible pathways for the release of this radioactive material. The first is by way of the N-VDS drawing atmosphere directly from the port cell, and after detritiating and filtering this vapor stream, exhausting it to the environment. The second pathway will be leakage from the port cell into the gallery. Once in the gallery, the radioactivity will be released by either leakage through the gallery walls to the environment, exhausted from the gallery to the environment by way of the Heating Ventilation and Air Conditioning (HVAC) system, or exhausted to the environment by way of the S-VDS. For this event, the gallery HVAC was isolated, presumably due to the actuation of the S-VDS. The latter two releases will be filtered and detritiated prior to release. The third pathway is through the port cell pressure relief panel, when the port cell pressure relief causes the atmosphere of the port cell to flow into the TCWS vault by way of the pipe chase and in doing so sweeps radioactive material into the vault as well. Once inside the vault, this radioactivity can reach the environment by either leakage through the vault walls or N-VDS cleanup of the vault atmosphere. Vault leakage will be unfiltered, but the N-VDS stream will be detritiated and filtered prior to release to the environment. The last wave form of Figure 3 presents the predicted mass of ACP and tritium in the vault for this event. Table 2-3 summarized the losses by these pathways during the first 36 hours of this event. Since the ITER accidental release limits for tritium as HTO and ACP are $5 \mathrm{~g}$ and $50 \mathrm{~g}$ [How07], respectively, the releases predicted for this event $\left(1.9 \times 10^{-4} \mathrm{~g}\right.$-T as HTO and $1.0 \times 10^{-2} \mathrm{~g}$ of ACP $)$ are well below ITER limits. 
Table 2-3. Mobilized Inventory, Transport and Release to Environment in Coolant Leak into Port Cell Event

\begin{tabular}{|c|c|c|c|}
\hline $\begin{array}{l}\text { Mobilized } \\
\text { Inventory }\end{array}$ & Release path, transport of inventory & $\begin{array}{l}\text { Release } \\
\text { amount }\end{array}$ & Total release \\
\hline \multirow[t]{3}{*}{$\begin{array}{l}\text { Tritium in PHTS } \\
\text { loops } \\
0.7 \mathrm{~g}-\mathrm{T}\end{array}$} & $\begin{array}{l}\text { PHTS loops }>>\text { Port cell }(0.025 \mathrm{~g}-\mathrm{T})>> \\
\mathrm{N}-\mathrm{VDS}>>\text { environment; plus TCWS } \\
\text { vault }\left(3.9 \times 10^{-4} \mathrm{~g}-\mathrm{T}\right)>>\mathrm{N}-\mathrm{VDS}>> \\
\text { environment }\end{array}$ & $1.8 \times 10^{-9} \mathrm{~g}$ & \multirow{3}{*}{$\begin{array}{l}\text { Controlled release } \\
1.5 \times 10^{-4} \mathrm{~g}-\mathrm{T} \\
\text { Uncontrolled } \\
\text { release } \\
4.2 \times 10^{-5} \mathrm{~g}-\mathrm{T} \\
\text { Total release } \\
1.9 \times 10^{-4} \mathrm{~g}-\mathrm{T} \text { as HTO }\end{array}$} \\
\hline & $\begin{array}{l}\text { PHTS loops }>>\text { Port cell }(0.025 \mathrm{~g}-\mathrm{T})>> \\
\text { gallery }(0.013 \mathrm{~g}-\mathrm{T})>>\mathrm{S}-\mathrm{VDS} / \mathrm{HVAC}>> \\
\text { environment }\end{array}$ & $1.5 \times 10^{-4} \mathrm{~g}$ & \\
\hline & $\begin{array}{l}\text { PHTS loops }>>\text { Port cell }(0.025 \mathrm{~g}-\mathrm{T})>> \\
\text { gallery }(0.013 \mathrm{~g}-\mathrm{T})>>\text { leakage from } \\
\text { the gallery }>>\text { environment; plus port cell } \\
>>\text { TCWS vault }\left(3.9 \times 10^{-4} \mathrm{~g} \mathrm{~T}\right)>>\text { leakage } \\
\text { from the vault }>>\text { environment }\end{array}$ & $4.2 \times 10^{-5} \mathrm{~g}$ & \\
\hline \multirow[t]{3}{*}{$\begin{array}{l}\text { ACP in one PHTS } \\
\text { loop } \\
10 \mathrm{~kg}\end{array}$} & $\begin{array}{l}\text { PHTS loops }>>\text { Port cell }(4.4 \mathrm{~g})>> \\
\mathrm{N}-\text { VDS }>>\text { environment; plus TCWS } \\
\text { vault }\left(8.8 \times 10^{-2} \mathrm{~g}\right)>>\mathrm{N}-\mathrm{VDS}>> \\
\text { environment }\end{array}$ & $5.3 \times 10^{-8} \mathrm{~g}$ & \multirow{3}{*}{$\begin{array}{l}\text { Controlled release } \\
6.9 \times 10^{-4} \mathrm{~g} \\
\text { Uncontrolled } \\
\text { release } \\
1.0 \times 10^{-2} \mathrm{~g} \\
\text { Total release } \\
1.0 \times 10^{-2} \mathrm{~g}\end{array}$} \\
\hline & $\begin{array}{l}\text { PHTS loops }>>\text { Port cell }(4.4 \mathrm{~g})>> \\
\text { gallery }(3.3 \mathrm{~g})>>\text { S-VDS/HVAC }>> \\
\text { environment }\end{array}$ & $6.9 \times 10^{-4} \mathrm{~g}$ & \\
\hline & $\begin{array}{l}\text { PHTS loops }>>\text { Port cell }(4.4 \mathrm{~g})>> \\
\text { gallery }(3.3 \mathrm{~g})>>\text { leakage from } \\
\text { the gallery }>>\text { environment; plus port cell } \\
>>\text { TCWS vault }\left(8.8 \times 10^{-2} \mathrm{~g}\right)>>\text { leakage } \\
\text { from the vault }>>\text { environment }\end{array}$ & $1.0 \times 10^{-2} \mathrm{~g}$ & \\
\hline
\end{tabular}

\subsection{Evaluation of Parameter Study Radiological Release}

Because the parameter cases examined a FW/BL PHTS loop while at baking conditions, there is no probable mechanism for simultaneously failing the ITER FW for these parameter cases; and as a consequence, the radioactive inventories inside of the VV are not mobilized by these scenarios. However, the radioactive materials mobilized for these scenarios are the tritium (HTO) and activated corrosion products (ACP) from within of the failed FW/BL PHTS cooling loop. The maximum tritium concentration of the FW/BL coolant is $0.005 \mathrm{~g}$ $\mathrm{T} / \mathrm{m}^{3}$ [SAD07]. The fraction of this HTO that is mobilized into the atmosphere of the port cell is $100 \%$ of the HTO in the PHTS water that spills into this structure. The quantity of ACP in a FW/BL PHTS loop is $10 \mathrm{~kg}$ [SAD07]. The fraction of the ACP mobilized into the VV or port cell atmosphere during this event is $1.3 \%$ of the ACP in the water inventory spilled [SAD07]. Given that the quantity of water spilled from the FW/BL PHTS during the parameter case with port cell bypass is 2.3 tonnes, the resulting mass of tritium and ACP mobilized are $\sim 1.3 \times 10^{-2}$ $\mathrm{g}-\mathrm{T}$ and $2.5 \mathrm{~g} \mathrm{ACP}$. The amount of water spilled into the port cell for the parameter case without port cell bypass is 98 tonnes, which mobilizes $0.57 \mathrm{~g}-\mathrm{T}$ and $105.3 \mathrm{~g} \mathrm{ACP}$. This compares with $0.025 \mathrm{~g}$ of tritium and $4.4 \mathrm{~g}$ of ACP mobilized inside of the port cell for the base case. 
Because the port cell pressures are higher for the parameter cases than the base case, more tritium and ACP mass was transported/leaked into the vault/gallery for the parameter cases; and once inside the vault and gallery, more tritium and ACP mass was leaked to the environment. The masses of tritium and ACP leaked into the gallery for the parameter case with port cell bypass are $5.8 \times 10^{-3} \mathrm{~g}-\mathrm{T}$ (as HTO) and $1.4 \mathrm{~g}$ of ACP. The masses of tritium and ACP leaked into the gallery for the parameter case without port cell bypass are $\sim 0.14 \mathrm{~g}-\mathrm{T}$ (as HTO) and $\sim 49 \mathrm{~g}$ of ACP. These numbers compare to $1.3 \times 10^{-2} \mathrm{~g}-\mathrm{T}$ (as HTO) and $4.4 \mathrm{~g}$ of ACP for the base case scenario. The masses of tritium and ACP swept into the vault for the parameter case with port cell bypass are $8.6 \times 10^{-4} \mathrm{~g}-\mathrm{T}$ (as HTO) and $3.5 \times 10^{-2} \mathrm{~g}$ of ACP. The masses of tritium and ACP swept into the vault for the parameter case without port cell bypass are $2.0 \times 10^{-2} \mathrm{~g}$ - $\mathrm{T}$ (as HTO) and $\sim 8.8 \mathrm{~g}$ of ACP. These numbers compare to $3.9 \times 10^{-4} \mathrm{~g}-\mathrm{T}$ (as HTO) and $8.8 \times 10^{-2} \mathrm{~g}$ of ACP for the base case scenario.

The releases for these parameter cases are compared to the base case accident scenario in Table 2-4. In the pathway column of this table, the masses mobilized or transported into the locations listed are given in respective order of base case, parameter case with port cell bypass, and parameter case without port cell bypass. The same ordering was also used for the total release column. The individual pathway releases are listed by case title, that is as base, bypass (port cell bypass), and no bypass (without port cell bypass). The total release to the environment for the parameter case with bypass is $5.8 \times 10^{-3} \mathrm{~g}-\mathrm{T}$ (as HTO) and $1.6 \times 10^{-2} \mathrm{~g}$ of $\mathrm{ACP}$, and that for the parameter case without bypass to $3.0 \times 10^{-2} \mathrm{~g}-\mathrm{T}$ (as HTO) and $11.4 \mathrm{~g}$ of ACP. These numbers compare to $1.9 \times 10^{-4} \mathrm{~g}-\mathrm{T}$ as HTO and $1.0 \times 10^{-2} \mathrm{~g}$ of ACP for the base case scenario.

It is interesting to note how the gallery safety systems responded to the three cases analyzed. The gallery HVAC system isolated the gallery in all three cases studied. However, in the baking case with port cell bypass, the HVAC system restarts after 32 hours where for the other two scenarios the gallery remained isolated after 32 hours. The gallery S-VDS activated for the base case and the baking case without port cell bypass, but not for the baking scenario without port cell bypass because the gallery tritium concentration remained below the activation set point for this system. The S-VDS remained in the $95 \%$ efficiency mode for the base case, but switched into the $99 \%$ efficiency mode 30 minutes after gallery isolation. These operational scenarios lead to the noticeable differences in Table 2-4, for example, the baking case with port cell bypass the S-VDS/HVAC releases are higher than both of the other two cases. Because these releases were by way of the HVAC system, the releases were recorded in Table 2-4 as an uncontrolled tritium release (e.g. not detritiated) and a controlled ACP release (e.g. filtered).

The result that stands out most Table 2-4 is the dramatic increase in the released mass of ACP for the parameter case without port cell bypass. In examining the results from the MELCOR code, it appears that this is entirely due to leakage from the gallery during this parameter case. The leakage from the gallery during the base case and parameter case with port cell bypass is essentially nil, while for the parameter case without port cell bypass the leakage from the gallery reaches a maximum of $\sim 24$ tonnes by 2.5 hours, after which point the gallery leakage reverses and begins to flow into the gallery from the environment. In addition, the leakage from the port cell to the gallery continues for $\sim 10$ hours during this parameter case which is $\sim 9$ hours after the port cell relief panel to the pipe chase reseats. However, while there was a substantial increase in the ACP release, the releases are still below the release limits for ITER of $5 \mathrm{~g}$-T (as HTO) and $50 \mathrm{~g}$ of ACP, demonstrating no cliff-edge effect for these parameter cases. 
Table 2-4. Mobilized Inventory, Transport and Release to Environment for Coolant Leak into Port Cell Event Parameter Cases

\begin{tabular}{|c|c|c|c|c|}
\hline $\begin{array}{l}\text { Mobilized } \\
\text { Inventory }\end{array}$ & Release path, transport of inventory & $\begin{array}{l}\text { Parameter } \\
\text { Case }\end{array}$ & $\begin{array}{l}\text { Release } \\
\text { amount }\end{array}$ & Total release \\
\hline \multirow{9}{*}{$\begin{array}{l}\text { Tritium in } \\
\text { PHTS loops } \\
0.7 \text { g-T }\end{array}$} & \multirow{3}{*}{$\begin{array}{l}\text { PHTS loops }>>\text { Port cell }(0.025,0.013 \text {, } \\
0.57 \text { g-T })>>\text { N-VDS }>>\text { environment; } \\
\text { plus TCWS vault }\left(3.9 \times 10^{-4}, 8.6 \times 10^{-4}\right. \\
\left.2.0 \times 10^{-2} \text { g-T }\right)>>\text { N-VDS }>> \\
\text { environment }\end{array}$} & Base & $1.8 \times 10^{-9} \mathrm{~g}$ & \multirow{9}{*}{$\begin{array}{l}\text { Controlled } \\
\text { release: } \\
1.5 \times 10^{-4} \text {, } \\
3.3 \times 10^{-9}, \\
6.8 \times 10^{-5} \mathrm{~g}-\mathrm{T} \\
\text { Uncontrolled } \\
\text { release: } \\
4.2 \times 10^{-5} \text {, } \\
5.8 \times 10^{-3} \text {, } \\
3.0 \times 10^{-2} \mathrm{~g}-\mathrm{T} \\
\text { Total release: } \\
1.9 \times 10^{-4} \text {, } \\
5.8 \times 10^{-3} \text {, } \\
3.0 \times 10^{-2} \mathrm{~g}-\mathrm{T} \text { as } \\
\mathrm{HTO}\end{array}$} \\
\hline & & Bypass & $3.3 \times 10^{-9} \mathrm{~g}$ & \\
\hline & & No Bypass & $8.7 \times 10^{-8} \mathrm{~g}$ & \\
\hline & \multirow{3}{*}{$\begin{array}{l}\text { PHTS loops }>>\text { Port cell }(0.025,0.013, \\
0.57 \mathrm{~g}-\mathrm{T})>>\text { gallery }(0.013,0.0058, \\
0.14 \mathrm{~g}-\mathrm{T})>>\text { S-VDS/HVAC }>> \\
\text { environment }\end{array}$} & Base & $1.5 \times 10^{-4} \mathrm{~g}$ & \\
\hline & & Bypass & $5.7 \times 10^{-3} \mathrm{~g}$ & \\
\hline & & No Bypass & $6.8 \times 10^{-5} \mathrm{~g}$ & \\
\hline & \multirow{3}{*}{$\begin{array}{l}\text { PHTS loops }>>\text { Port cell }(0.025,0.013, \\
0.57 \mathrm{~g}-\mathrm{T})>>\text { gallery }(0.013,0.0058, \\
0.14 \mathrm{~g}-\mathrm{T})>>\text { leakage from the gallery } \\
>>\text { environment; plus port cell }>> \\
\text { TCWS vault }\left(3.9 \times 10^{-4}, 8.6 \times 10^{-4},\right. \\
\left.2.0 \times 10^{-2} \mathrm{~g} \mathrm{~T}\right)>>\text { leakage from the vault } \\
>>\text { environment }\end{array}$} & Base & $4.5 \times 10^{-5} \mathrm{~g}$ & \\
\hline & & Bypass & $1.2 \times 10^{-4} \mathrm{~g}$ & \\
\hline & & No Bypass & $3.0 \times 10^{-2} \mathrm{~g}$ & \\
\hline \multirow{9}{*}{$\begin{array}{l}\text { ACP in one } \\
\text { PHTS loop } \\
10 \mathrm{~kg}\end{array}$} & \multirow{3}{*}{$\begin{array}{l}\text { PHTS loops }>>\text { Port cell }(4.4,2.5, \\
105.3 \mathrm{~g})>>\mathrm{N}-\mathrm{VDS}>>\text { environment; } \\
\text { plus TCWS vault }(0.088,0.035,8.8 \mathrm{~g}) \\
>>\mathrm{N}-\mathrm{VDS}>>\text { environment }\end{array}$} & Base & $5.3 \times 10^{-8} \mathrm{~g}$ & \multirow{9}{*}{$\begin{array}{l}\text { Controlled } \\
\text { release: } \\
6.9 \times 10^{-4}, \\
2.7 \times 10^{-8}, \\
1.1 \times 10^{-3} \mathrm{~g} \\
\text { Uncontrolled } \\
\text { release: } \\
1.0 \times 10^{-2} \text {, } \\
8.0 \times 10^{-3}, \\
11.4 \mathrm{~g} \\
\text { Total release: } \\
1.0 \times 10^{-2} \text {, } \\
1.6 \times 10^{-2}, \\
11.4 \mathrm{~g}\end{array}$} \\
\hline & & Bypass & $2.7 \times 10^{-8} \mathrm{~g}$ & \\
\hline & & No Bypass & $3.2 \times 10^{-7} \mathrm{~g}$ & \\
\hline & \multirow{3}{*}{$\begin{array}{l}\text { PHTS loops }>>\text { Port cell }(4.4,2.5, \\
105.3 \mathrm{~g})>>\text { gallery }(3.3,1.4,49 \mathrm{~g})>> \\
\text { S-VDS/HVAC }>>\text { environment }\end{array}$} & Base & $6.9 \times 10^{-4} \mathrm{~g}$ & \\
\hline & & Bypass & $7.5 \times 10^{-3} \mathrm{~g}$ & \\
\hline & & No Bypass & $1.1 \times 10^{-3} \mathrm{~g}$ & \\
\hline & \multirow{3}{*}{$\begin{array}{l}\text { PHTS loops }>>\text { Port cell }(4.4,2.5, \\
105.3 \mathrm{~g})>>\text { gallery }(3.3,1.4,49 \mathrm{~g})>> \\
\text { leakage from the gallery }>> \\
\text { environment; plus port cell }>>\text { TCWS } \\
\text { vault }(0.088,0.035,8.8 \mathrm{~g})>>\text { leakage } \\
\text { from the vault }>>\text { environment }\end{array}$} & Base & $1.0 \times 10^{-2} \mathrm{~g}$ & \\
\hline & & Bypass & $8.0 \times 10^{-3} \mathrm{~g}$ & \\
\hline & & No Bypass & $11.4 \mathrm{~g}$ & \\
\hline
\end{tabular}

\subsection{Uncertainties in the Results}

There is some uncertainty regarding these analyses that is due to the simplistic modeling of radioactive source terms, and the level of detail used to model the ITER plant. In the analyses, conservative assumptions are used such that more detailed modeling should not result in higher releases; for example, the assumption regarding mobilization of radioactivity. In addition, these radioactive source terms (FW/BL-PHTS tritium and ACP) will be controlled by operational procedures, in which case all of the tritium could be released and a confinement factor of only $\sim 3$ would be required for the mobilized ACP to remain below ITER release limits.

However, some uncertainty does exist in the mobilization assumptions of the airborne corrosion products. Based on a literature survey, the initial airborne corrosion product concentration could be up to $10 \%$ of the spilled water instead of $1.3 \%$. This might increase the airborne environmental release by a factor of eight [GSSR04].

There is also some uncertainty regarding the MELCOR code's ability to accurate predict VV and port cell pressure for this event. However, based on validation studies presented in [Top01] and 
[Sar06], the MELCOR code is capable of correctly predicting pressures for these conditions, provided that attention is given to providing this code with adequate modeling details of the ITER device.

\subsection{Summary}

The coolant leak into port cell event was selected as one of the accident events because it demonstrates the design approach to minimizing the consequences of severe pressurization events in ITER, both for the VV and the confinement building. The objective is to show that accidental overpressure in the port cell will be safely mitigated and that the radioactive releases are adequately confined; that is, that the accidental releases are below the ITER accidental release limits.

During this event, the port cell pressure will reach the port cell relief panel actuation pressure within seconds. Once the port cell relief panel opens, the pressure in this cell is maintained at $120 \mathrm{kPa}$ until the port cell bypass valves actuate (60 s after start of event) restoring the port cell pressure to $100 \mathrm{kPa}$ by $250 \mathrm{~s}$. The bleed line to the VV ST opens at $\sim 88$ $\mathrm{s}$, limiting the VV pressure to a maximum value of $93 \mathrm{kPa}$. Once the bleed line opens to the $\mathrm{ST}$, the VV pressure begins to drop because the steam flow rate into the ST through the bleed line exceeds the water flow rate from the FW break that is expelling water into the VV from the FW/BL PHTS. The predicted maximum port cell and VV pressures are well below the design pressures for these structures.

Because the high pressure source in this event is the damaged FW/BL PHTS, the radioactivity mobilized within the VV during this accident was not transported into the port cell. In addition, because the port cell was isolated within $60 \mathrm{~s}$ of the occurrence of the FW/BL PHTS pipe break, the only radioactive inventories released into the port cell during this event are the tritium and ACP associated with the water spill from the PHTS into the port cell. The radioactivity mobilized within the port cell for this event was $0.026 \mathrm{~g}$-T as HTO and $4.8 \mathrm{~g}$ of ACP. The quantity of radioactivity released during this event was predicted to be $6.4 \times 10^{-5} \mathrm{~g}-\mathrm{T}$ as HTO and $1.2 \times 10^{-2} \mathrm{~g}$ of ACP, which is well below the ITER accidental release limits for tritium as HTO and ACP are $5 \mathrm{~g}$ and $50 \mathrm{~g}$ [How07], respectively.

To examine the safety margins associated with this event, two additional parameter studies were analyzed. These parameter studies examine the same PIE but do so when the ITER device is at baking conditions, resulting in a FW/BL PHTS system temperature of $250{ }^{\circ} \mathrm{C}$. The difference between these two parameter studies is that the first takes credit for the actuation of a port cell FW/BL PHTS bypass system, within $60 \mathrm{~s}$ of a $5 \mathrm{kPa}$ pressure increase in the port cell, and second parameter study does not. In both cases the port cell pressure remained below the port cell design pressure of $160 \mathrm{kPa}$. Because the parameter cases examined ITER response at baking conditions, the ITER FW was not damaged during these scenarios, resulting in the only radioactivity being mobilized being the tritium and ACP within the damaged loop. The predicted releases of both parameter cases remained below the ITER accidental release limits. 


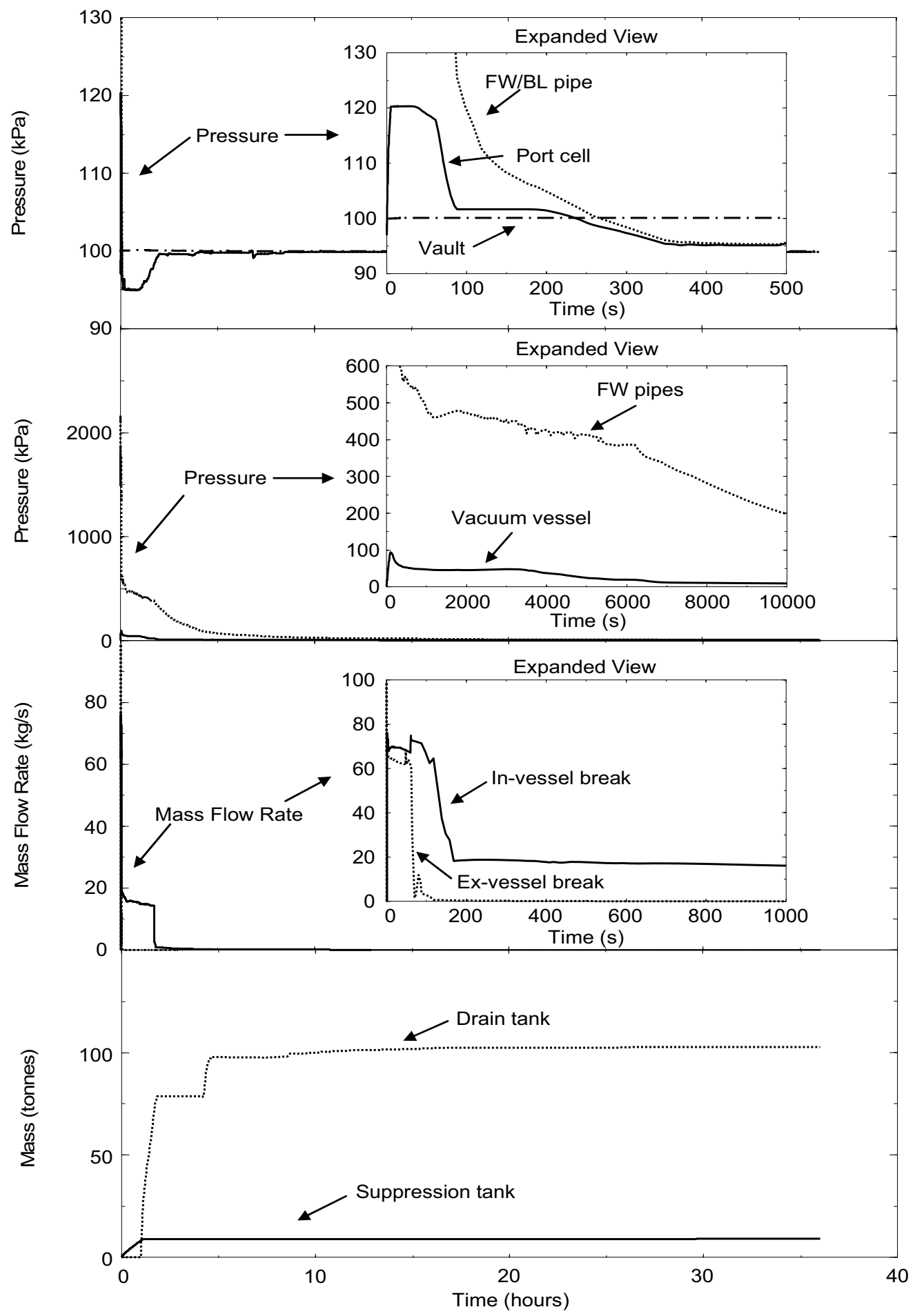

Figure 1. Time Transient of Physical Quantities for the Port Cell Leak Event following a FW/BL PHTS $66 \mathrm{~mm}$ pipe break in the Port Cell and a FW break into the VV 


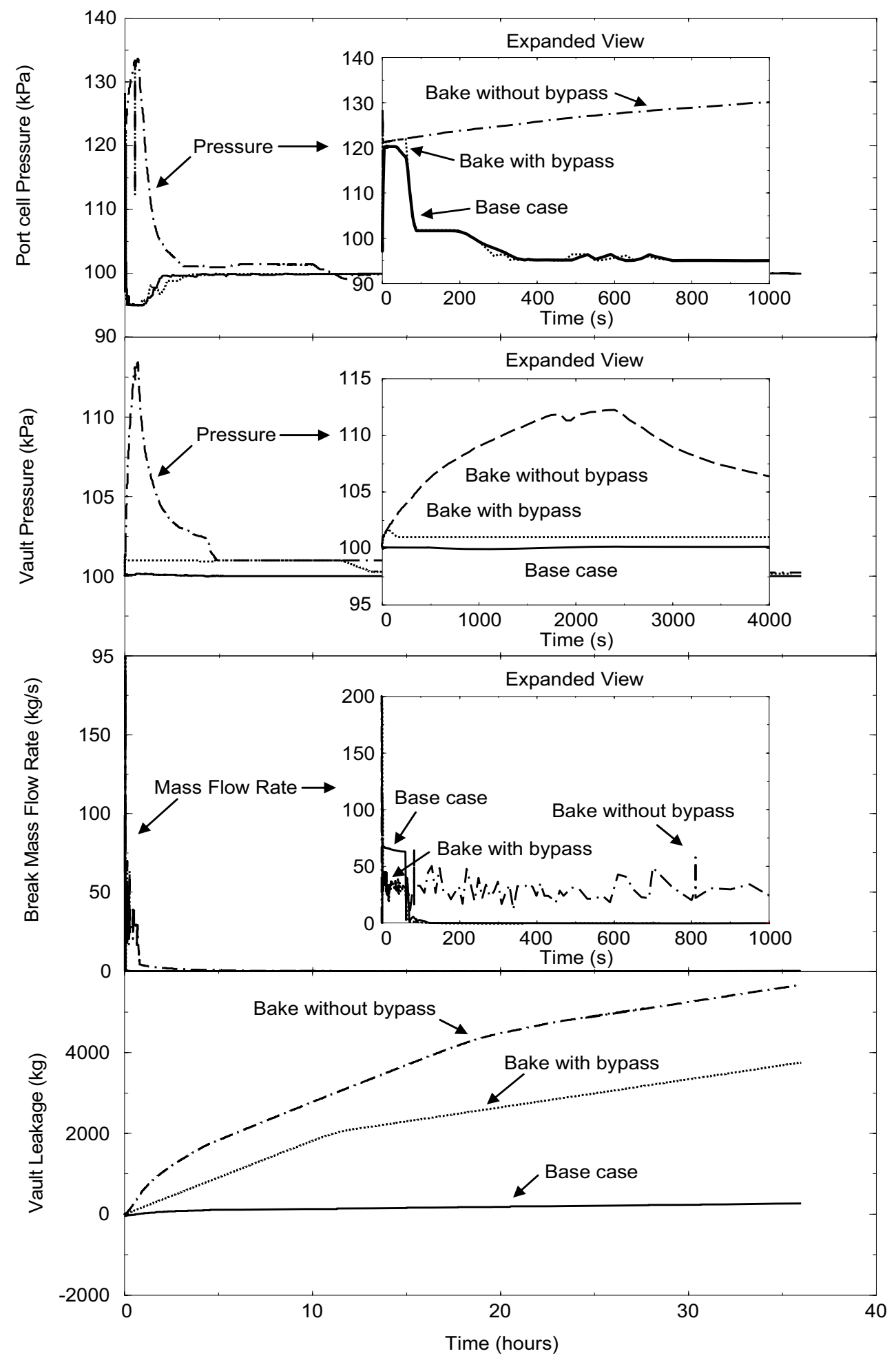

Figure 2. Time Transient of Physical Quantities for the Port Cell Leak Event following a FW/BL PHTS $66 \mathrm{~mm}$ pipe break during normal and baking PHTS conditions 


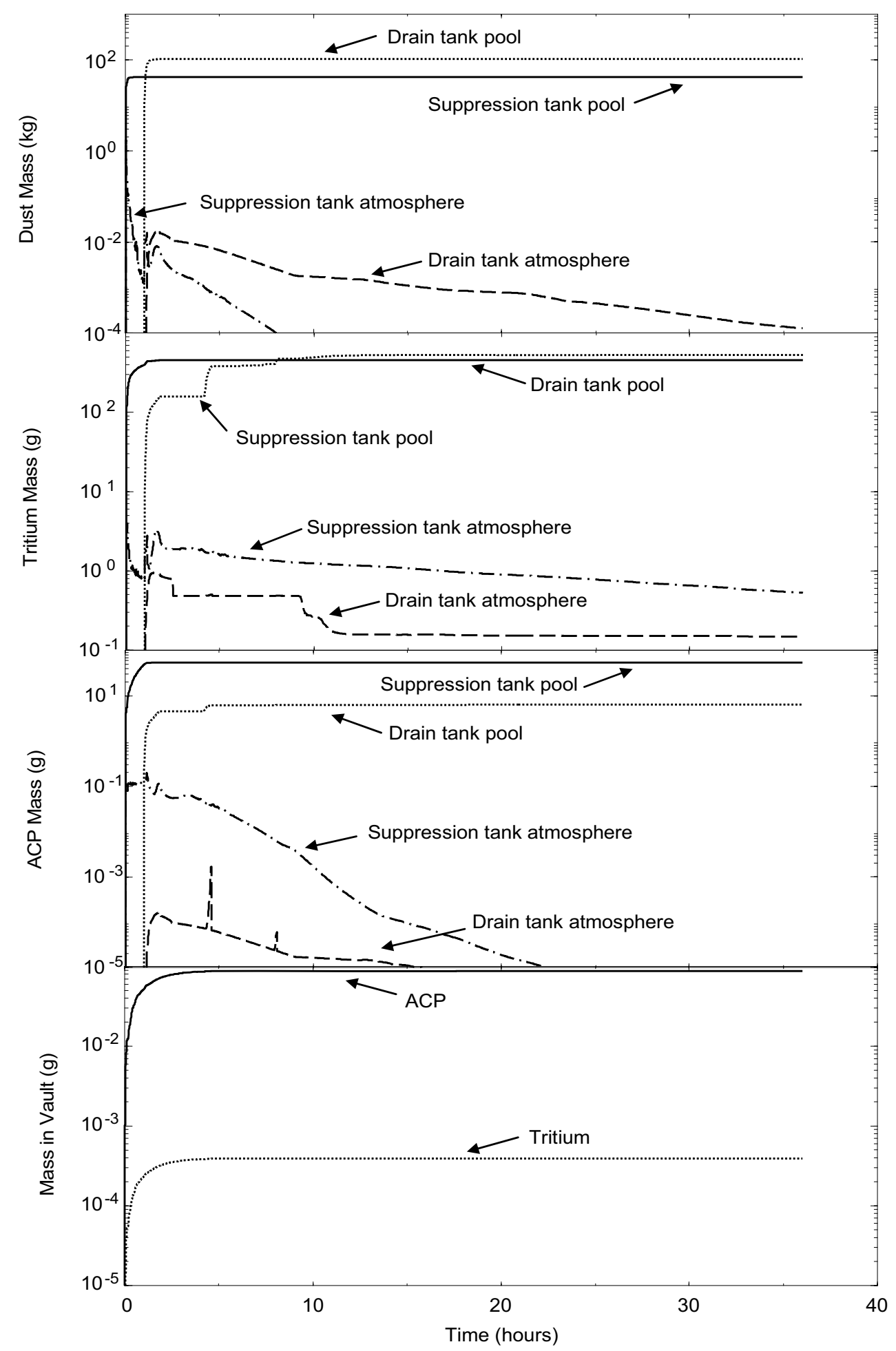

Figure 3. Time Transient of Radioactive Quantities for the Port Cell Leak Event following a FW/BL PHTS $66 \mathrm{~mm}$ pipe break during normal PHTS conditions 


\section{Cryostat Water Ingress Event}

This accident was chosen for consideration in the ITER RPrS as a DBA because it challenges the integrity of the ITER cryostat, which is a secondary confinement boundary of the ITER device. While very little radioactivity is mobilized by this accident, the failure of cryostat could lead to the possible mobilization of radioactive material from within the PHTS of ITER into the ITER confinement building and subsequently release of this material to the environment as a result of confinement building pressurization. The following subsections of this report section give the details surrounding this event, the assumptions used to model and analyze this accident, and the predicted consequences to ITER and the radioactive releases to the environment.

\subsection{Identification of Causes and Accident Description}

A single pipe from a cooling loop with the maximum coolant enthalpy, which is the first wall/blanket primary heat transport system (FW/BL PHTS) loop, is postulated to fail as it runs inside of the ITER cryostat. A double-ended off-set guillotine break of a pipe section with the largest diameter (ID $=66 \mathrm{~mm}$ ) inside of the ITER cryostat is postulated to occur. The pressure difference between the FW/BL PHTS cooling loop ( $3 \mathrm{MPa})$ and the cryostat $\left(10^{-4} \mathrm{~Pa}\right)$ will cause the coolant from the damaged loop to blow down as a steam/water mixture into the cryostat.

Within the cryostat are massive steel structures that operate at cryogenic temperatures $(4 \mathrm{~K})$, such as the ITER toroidal field (TF) coil cases. These structures will condense and freeze the steam being expelled into the cryostat from the damaged loop. As these structures condense this steam, they will increase in temperature, since the cryogenic cooling systems of these components are not designed for a heat load of this magnitude. An increase in the temperature of TF magnets will cause the superconducting windings of these magnets to undergo a thermal quench. Within seconds of the onset of this quench, the magnet quench protection system will detect the quench and activate the magnet fast discharge system, which will resistively decay the magnet current within the TF coil dump resistors. As the magnet current is lost, the magnetic field that confines the ITER plasma will decay leading to a plasma burn termination and thereby terminating the direct nuclear heating of the FW/BL structures that are being cooled by the damaged cooling loop. This process is estimated to take place within $30 \mathrm{~s}$ after the initiation of the loop break [AAS07]. No credit is taken for the actuation of the ITER fast plasma termination system (FPTS), which should actuate once the flow within the failed loop drops to $20 \%$ of its normal operating value [SAD07].

The accident is assumed to occur coincident with a 32 hour loss of offsite power, aggravated by a 1 hour station blackout due to an assumed loss of class-III emergency AC generator power [AAS07]. The result will be a loss of forced convection cooling as pumps

within the intact FW/BL, divertor, and the vacuum vessel (VV) cooling loops coast to a stop in 32 $\mathrm{s}$ following the loss of pump power [SAD07]. The VV cooling loop will transition into the natural convection heat transfer mode upon loss of pumping power and begin to remove in-vessel component decay heat by this heat transfer mode [SAD07]. Table 3-1 lists the sequence of events that have been determined for this accident scenario. 
The objectives of this accident analysis are to demonstrate that the:

- Accidental overpressure will be safely accommodated by the cryostat (maximum cryostat pressure with safety margin is $180 \mathrm{kPa}$ )

- Show that radioactive releases are adequately confined (radioactive releases are less than ITER accident release limits)

To examine the safety margins associated with this event, two additional parameter studies were analyzed for this accident, which are:

- A VV cooling loop pipe break, $0.1 \mathrm{~m}^{2}$ break size

- The simultaneous breach of $16 \mathrm{FW} / \mathrm{BL}$ cooling pipes

Listed below is the safety relevant system for this accident:

- Cryostat design pressure is $200 \mathrm{kPa}$ ( $2^{\text {nd }}$ radioactive confinement barrier)

Table 3-1. Time Sequence of Events for Cryostat Water Ingress

\begin{tabular}{|l|l|}
\hline Event Sequence & Time \\
\hline Failure of the FW/BL loop and helium cooling loop & 0 seconds \\
\hline TF, CS and PF coils discharge & 15 seconds \\
\hline Maximum break flow rate $(\sim 245 \mathrm{~kg} / \mathrm{s})$ reached & $\sim 2$ seconds \\
\hline Cryostat peak pressure $(10 \mathrm{kPa})$ reached & $\sim 21$ seconds \\
\hline Plasma termination & 30 seconds \\
\hline Break flow rate drops below $2.5 \mathrm{~kg} / \mathrm{s}$ & $\sim 1600 \mathrm{~s}$ \\
\hline Cryostat pressure drops below $4000 \mathrm{~Pa}$ & $\sim 1$ hour \\
\hline
\end{tabular}

\subsection{Method of Analysis}

A modified version of the MELCOR code was used for this analysis [Moo07a]. The MELCOR code was used to calculate the resulting coolant flow, pressures and temperatures within the cryostat, cryostat space room, gallery and FW/BL-PHTS. MELCOR was also used to calculate structure temperatures of the coil structures and the condensation and freezing of steam on these structures. Table 3-2 lists the major assumptions used in this analysis.

For this accident scenario, the thermal behavior of the TF coils, the gravity supports, the PF coils, CS coils, vacuum vessel (VV), VV thermal shields, cryostat walls, and cryostat thermal shields were simulated. All thermal properties extended down to cryogenic temperatures for this analysis [SAD07]. The MELCOR input deck used for this analysis is that developed by [Top07], which contains a representation of these ITER components, plus representations of the three FW/BL cooling systems and internal VV components, the divertor cooling system and internal VV components, and the VV cooling system and VV walls. Nuclear heating was included for the VV internal components both during plasma operation and decay heat, plus the surface heating to the internal components due to plasma radiant heat and particle losses. While not actuated by this accident scenario, this input model for MELCOR contained a representation of the VV pressure suppression system. A detailed description of this model can be found in [Top07]. The input deck used in this study was obtained from the ITER Document Management (IDM) system and had the designation of: CryostatWaterHeIngress_276UVK_3_4.inp. This input deck, with minor revisions identified by [Moo07b], was verified to conform to both the [SAD07] and [AAS07] by [Moo07b]. 
Table 3-2. Parameters and Initial Conditions Used in Cryostat Water Ingress Analysis

\begin{tabular}{|c|c|}
\hline Parameter & Value \\
\hline Break size & FW/BL cooling loop pipe diameter: $66 \mathrm{~mm}$ \\
\hline Coolant temperature of FW/BL PHTS [Tin/Tout] & $100 / 148^{\circ} \mathrm{C}$ \\
\hline FW/BL PHTS coolant inventory/loop & $130 \mathrm{~m}^{3}$ \\
\hline Cryostat free volume & $8442 \mathrm{~m}^{3}$ \\
\hline Cryostat leak rate & $1 \%$ volume/day at the design pressure \\
\hline Cryostat condensation area & $\begin{array}{l}8570 \mathrm{~m}^{2}\left(\mathrm{TF} \text { coils }=5230 \mathrm{~m}^{2}, \mathrm{PF} \text { coils }=2450 \mathrm{~m}^{2},\right. \\
\left.\mathrm{CS} \text { coils }=890 \mathrm{~m}^{2}\right)\end{array}$ \\
\hline Mass in cryostat & $\begin{array}{l}9295 \text { tonnes }(\mathrm{TF} \text { coils }=5620 \text { tonnes, } \mathrm{PF} \text { coils }= \\
2750 \text { tonnes, and CS coils }=925 \text { tonnes })\end{array}$ \\
\hline Temperatures of structures & TF, PF, CS coils : $55 \mathrm{~K}$ after discharge \\
\hline Total volume of gallery (plus cryostat space room) & $72,000 \mathrm{~m}^{3}$ \\
\hline Gallery ventilation rate by HVAC & 24 air-volume/day ( $95 \%$ filter for particles) \\
\hline $\begin{array}{l}\text { Gallery and cryostat space room leak rate through } \\
\text { wall (ground release) }\end{array}$ & $\begin{array}{l}100 \% \text { volume/day } \\
\text { - No leak for sub-atmospheric conditions } \\
\text { - Linear function in the delta P range between }-0.3 \\
\text { and }+0.3 \mathrm{kPa} \text {, beyond this range the leak rate scales } \\
\text { with the square root of the pressure differential }\end{array}$ \\
\hline $\begin{array}{l}\text { Set point for room/HVAC isolation and for } \\
\text { actuating S-VDS }\end{array}$ & $>0.1 \mu \mathrm{g}-\mathrm{T} / \mathrm{m}^{3}$ in room \\
\hline Time delay for room/HVAC isolation & 30 seconds \\
\hline HVAC isolation & Power outage \\
\hline S-VDS processing rate & $\begin{array}{l}3,000 \mathrm{~m}^{3} / \text { hour } \\
\text {-time delay of } 5 \mathrm{~min} \text { for actuation }\end{array}$ \\
\hline S-VDS filtering efficiencies & $99 \%$ for HTO, $99.9 \%$ for dust \\
\hline
\end{tabular}

\subsection{Transient Analysis Results for Base Case}

The following wave forms shown in Figure 4 for this accident are:

- Cryostat and FW/BL loop pressures;

- Break mass flow rate;

- Cryostat vapor and TF magnet surface temperatures;

- Ice mass on magnetic field coil surfaces

The cryostat pressure reaches a maximum value of around $11.5 \mathrm{kPa}$ in about 21 seconds. The pressure peak quickly subsides as the break flow drops from a peak of $\sim 245 \mathrm{~kg} / \mathrm{s}$ to $\sim 80 \mathrm{~kg} / \mathrm{s}$ in $50 \mathrm{~s}$ and the condensation rate of steam vapor onto the cryogenic surfaces within the cryostat exceeds the mass flow rate from the broken FW/BL loop pipe. The pressure in the cryostat remains well below the design pressure of the cryostat over the first 36 hours of this event. By this time, site power has been restored and corrective actions could be taken manually to control cryostat pressure.

The FW surface temperature in the failed loop peaks at $510 \mathrm{~K}$ as the plasma heating continues during the loss of coolant accident from the FW/BL PHTS. After plasma termination this temperature drops to $390 \mathrm{~K}$ in 2 hours due to internal $\mathrm{BL}$ heat conduction then rises again to $420 \mathrm{~K}$ due to $\mathrm{BL}$ decay heating. The vapor temperature in the cryostat remains below the triple point temperature after $\sim 3$ hours. There is a fluctuation in this temperature as ice from the thermal shields melts and evaporates up until about 6 hours. The TF magnet temperature rises to 
$55 \mathrm{~K}$ at the initiation of this event, as per specifications in [AAS07], to simulate the magnet quench. By 36 hours, the surface temperature of the TF magnets is predicted to reach $\sim 120 \mathrm{~K}$. At this temperature, the magnet is still acting as a cryopump for water vapor.

Ice buildup on the magnets is predicted to continue over the 36 hours analyzed for this accident, as vapor from water/ice in contact with the cryostat wall continues to evaporate/sublimate. Of the 109 tonnes of water discharged from the FW/BL PHTS, approximately 22 tonnes exists as ice on magnet surfaces by 36 hours. The added weight to these structures is only an increase of $\sim 0.3 \%$, which should not result in any structural issues for the support structures of these magnets.

\subsection{Transient Analysis Results for Parameter Studies}

Two parameter cases were studied for this accident scenario. These parameter cases employed the same assumptions and modeling approach as the base case, but the first parameter case considers the simultaneous double-ended guillotine break of $16 \mathrm{FW} / \mathrm{BL}$ PHTS pipes inside of the cryostat, while the second parameter case considers a double-ended guillotine break of a single pipe of the VV PHTS inside of the cryostat. Wave forms shown in Figure 5 compare the results for these parameter cases with those of the base case scenario. These wave forms are:

- Cryostat pressure;

- Break mass flow rate;

- TF magnet surface temperature;

- TF magnet surface ice mass

The maximum pressure for these parameter cases is $\sim 38 \mathrm{kPa}$, which resulted from the 16 FW/BL PHTS pipe break case. This pressure was more than three times the peak for the base case. However, this pressure is still well below the maximum pressure that the cryostat can withstand $(200 \mathrm{kPa})$ and is still sub-atmospheric indicating that leakage out of the cryostat will not occur for the cases studied. Cryostat pressures for all cases drop below $6 \mathrm{kPa}$ by $4000 \mathrm{~s}$, with the pressure from the VV PHTS single pipe break resulting in a pressure that is $\sim 30 \%$ higher than the other cases after $4000 \mathrm{~s}$, due to the larger quantity of water expelled into the cryostat for this parameter case. Even though more water enters the cryostat for the VV PHTS single pipe break, the resulting peak cryostat pressure is less than the $16 \mathrm{FW} / \mathrm{BL}$ PHTS pipe break case due to the lower operating temperature, and consequently a lower saturation pressure, of the VV PHTS. The maximum break flow rates are $245 \mathrm{~kg} / \mathrm{s}, 1215 \mathrm{~kg} / \mathrm{s}$, and $415 \mathrm{~kg} / \mathrm{s}$ for the base, the $16 \mathrm{FW} / \mathrm{BL}$ pipe break, and the VV PHTS single pipe break cases, respectively. The quantity of water entering the cryostat for these same cases is 109 tonnes, 111 tonnes, and 249 tonnes, respectively.

The predicted TF magnet case surface temperatures for these three cases are very similar; with the VV PHTS single pipe break (which introduced the largest quantity of water into the cryostat) resulting in a temperature that is $\sim 5 \mathrm{~K}$ higher by 36 hours. The quantity of ice on the TF magnets varies dramatically among the three cases for the first 10 hours (due to rate of water injection and resulting pressure buildup), but by 40 hours the ice masses are within 5\%. None of the predicted ice masses represent a structural hazard to the magnets since they are less than $\sim 0.3 \%$ of the magnet's dry weight. The explanation for the plateau in the $16 \mathrm{FW} / \mathrm{BL}$ PHTS pipe break case is the more rapid steam condensation of this parameter case resulted in less water in contact with the cryostat floor, until around 22 hours when parts of the cryostat became warm enough to melt some of the ice attached to the cryostat thermal shields. However, even with this 
plateau, by 36 hours there is very little difference in the predicted ice mass buildup for the 16 FW/BL PHTS break and base cases.

\subsection{Evaluation of Radiological Release}

In this accident scenario, the mobilized radioactive materials are activated corrosion products (ACP) and tritium as tritiated water (HTO) from within the cooling loops. The maximum tritium concentration of the FW/BL coolant is $0.005 \mathrm{~g}-\mathrm{T} / \mathrm{m}^{3}$ [SAD07]. The fraction of this HTO that is mobilized into the atmosphere of the cryostat is $100 \%$ of the HTO in the water that spills into the cryostat. Given the fraction of water spilled from the FW/BL PHTS during this event, the amount of tritium mobilized is $\sim 0.58 \mathrm{~g}-\mathrm{T}$ as HTO. The quantity of ACP in a FW/BL PHTS loop is $10 \mathrm{~kg}$ [SAD07]. The fraction of the ACP mobilized into the cryostat atmosphere during this event is 1.3-\% of the ACP in the water inventory spilled [SAD07]. Given the fraction of FW/BL PHTS water spilled during this event, the total mobilized inventory of ACP is $\sim 108 \mathrm{~g}$.

The wave forms shown in Figure 6 are the radiological release results for the base case scenario. These wave forms are:

- Cryostat atmosphere tritium mass;

- Cryostat pool tritium mass;

- Cryostat atmosphere ACP mass;

- Cryostat pool ACP mass.

Because the pressure was limited in the cryostat to sub-atmospheric conditions, no leakage of radioactivity was calculated for the first 36 hours of this event. Therefore, the radioactive releases for this event do not exceed ITER Accident Release Limits. In addition, based on the fact that the predicted pressures are comparable to that for water at $30^{\circ} \mathrm{C}$, it is not likely that an overpressure condition will exist in the cryostat for this event even when the cryostat is warmed to room temperature conditions. As a consequence, the predicted total tritium and ACP masses in the cryostat are nearly constant in time. Because of the rapid condensation process that occurs in the cryostat during this event, most of the mobilized tritium (HTO) resides in the water/ice pool inside of the cryostat. It can also be seen that most of the mobilized ACP settles back onto the water/ice pool that forms at the bottom of the cryostat.

\subsection{Evaluation of Parameter Study Radiological Release}

There is very little difference between the quantity of water released into the cryostat by the $16 \mathrm{FW} / \mathrm{BL}$ PHTS pipe break case and the base case, within $2 \%$, indicating that the radioactive mobilization for these cases is virtually the same. The VV PHTS single pipe break releases more water than the other accident cases. However only $\sim 77 \%$ of this system's tritium and ACP are mobilized, in comparison to $\sim 90 \%$ for the FW/BL PHTS. Given that the tritium concentration in VV PHTS is 50 times lower than in the FW/BL PHTS, and the ACP concentration is $\sim 3$ times lower, the VV PHTS single pipe break case did not mobilize more radioactivity than the other accident cases. Finally since none of the parameter cases developed cryostat pressures in excess of atmospheric pressure, these scenarios do not prove to be more hazardous than the base case. 


\subsection{Uncertainties in Results}

There is some uncertainty regarding these analyses that is due to the simplistic modeling of radioactive source terms, and the level of detail used to model the ITER cryostat. In the analyses, conservative assumptions are used such that more detailed modeling should not result in higher releases, for example the assumption regarding mobilization of radioactivity. In addition, these radioactive source terms (FW/BL-PHTS tritium and ACP) will be controlled by operational procedures, in which case all of the tritium could be released and a confinement factor of only $\sim 3$ would be required for the mobilized ACP to remain below ITER release limits.

There is also some uncertainty regarding the MELCOR code's ability to accurate predict cryostat pressure for this event. However, based on validation studies presented in [Top01] and [Sar06], the MELCOR code is capable of correctly predicting pressures for these conditions, provided that attention is given to providing this code with adequate modeling details of the ITER device.

\subsection{Summary}

A single cooling pipe in one FW/BL PHTS is postulated to fail inside the cryostat. The cryostat pressure reaches a maximum value of around $10 \mathrm{kPa}$ in about 21 seconds and then quickly drops to below $5 \mathrm{kPa}$ within $1000 \mathrm{~s}$, where it stays for the remaining 36 hours analyzed for this event.

The masses of tritium and ACP mobilized during this event are $0.6 \mathrm{~g}$-T and $110 \mathrm{~g}$, respectively. None of this material is predicted to find its way to the environment during this accident. Therefore, because there are no radioactive releases to the environment for this accident scenario, the radioactive releases for this event do not exceed the ITER Accident Release Limits. 


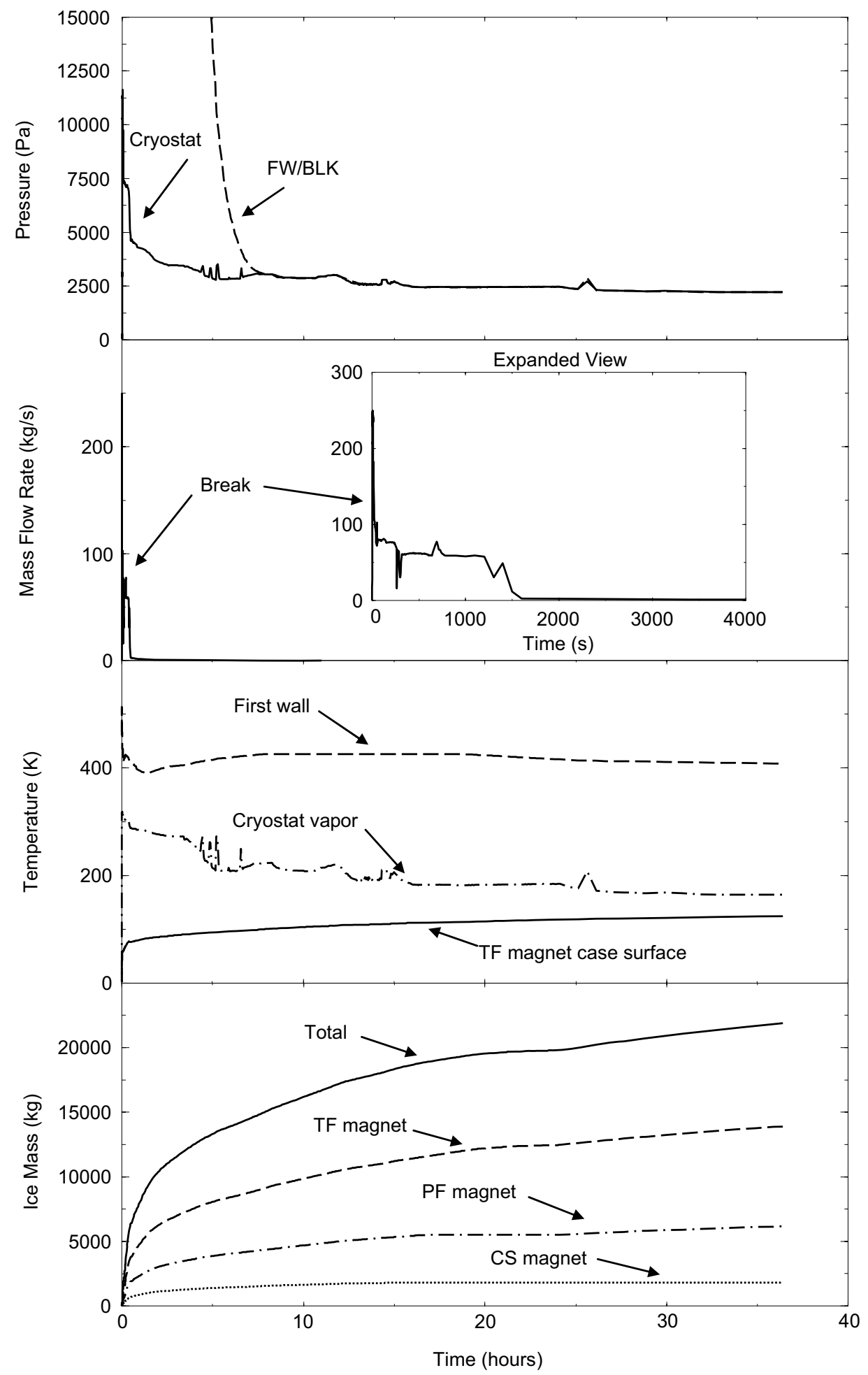

Figure 4. Time Transient of Physical Quantities for the Cryostat Water Ingress Event following a FW/BL PHTS break of a single $66 \mathrm{~mm}$ pipe 


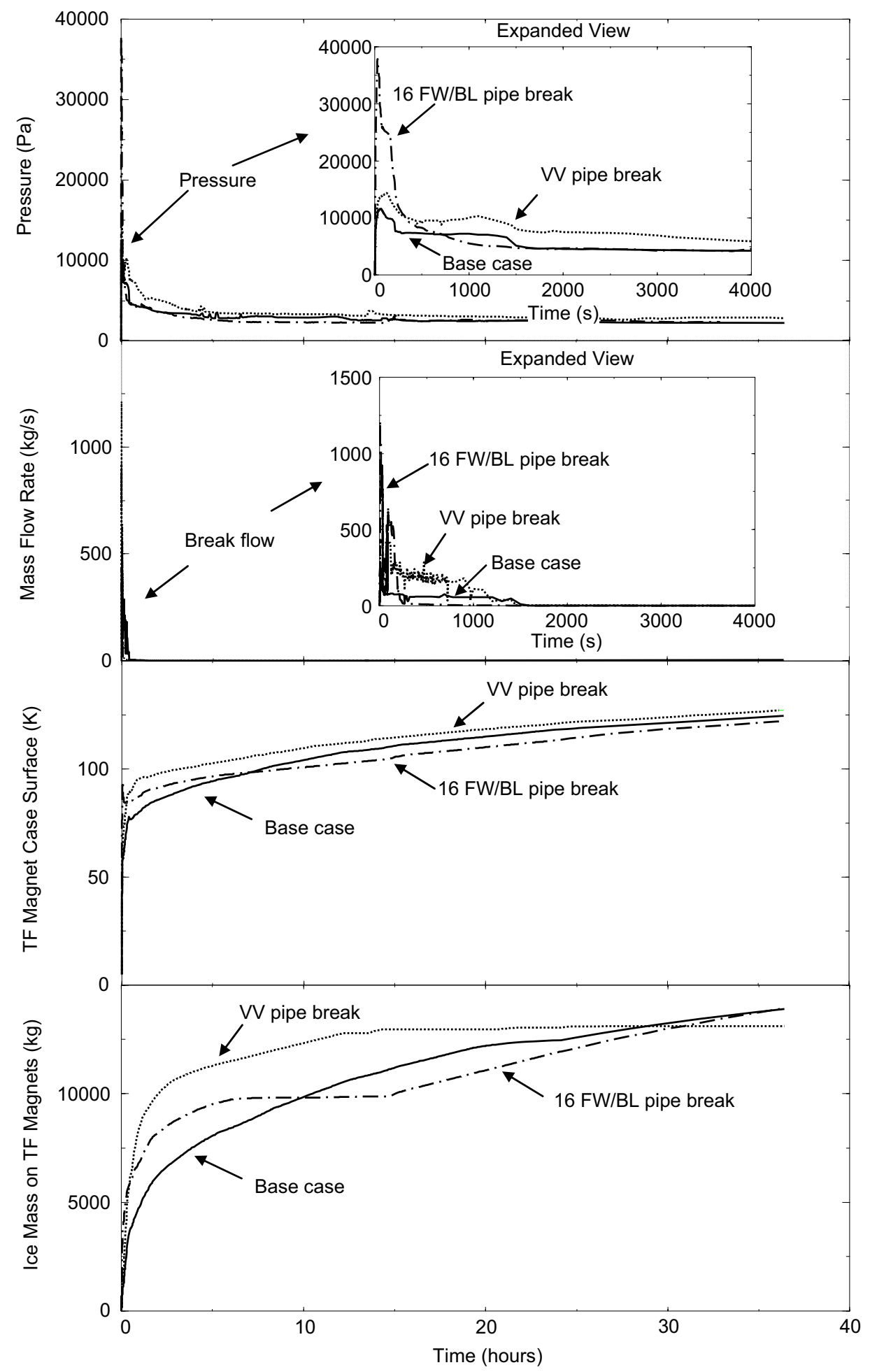

Figure 5. Time Transient of Physical Quantities for Parameter Studies for the Cryostat Water Ingress Event 


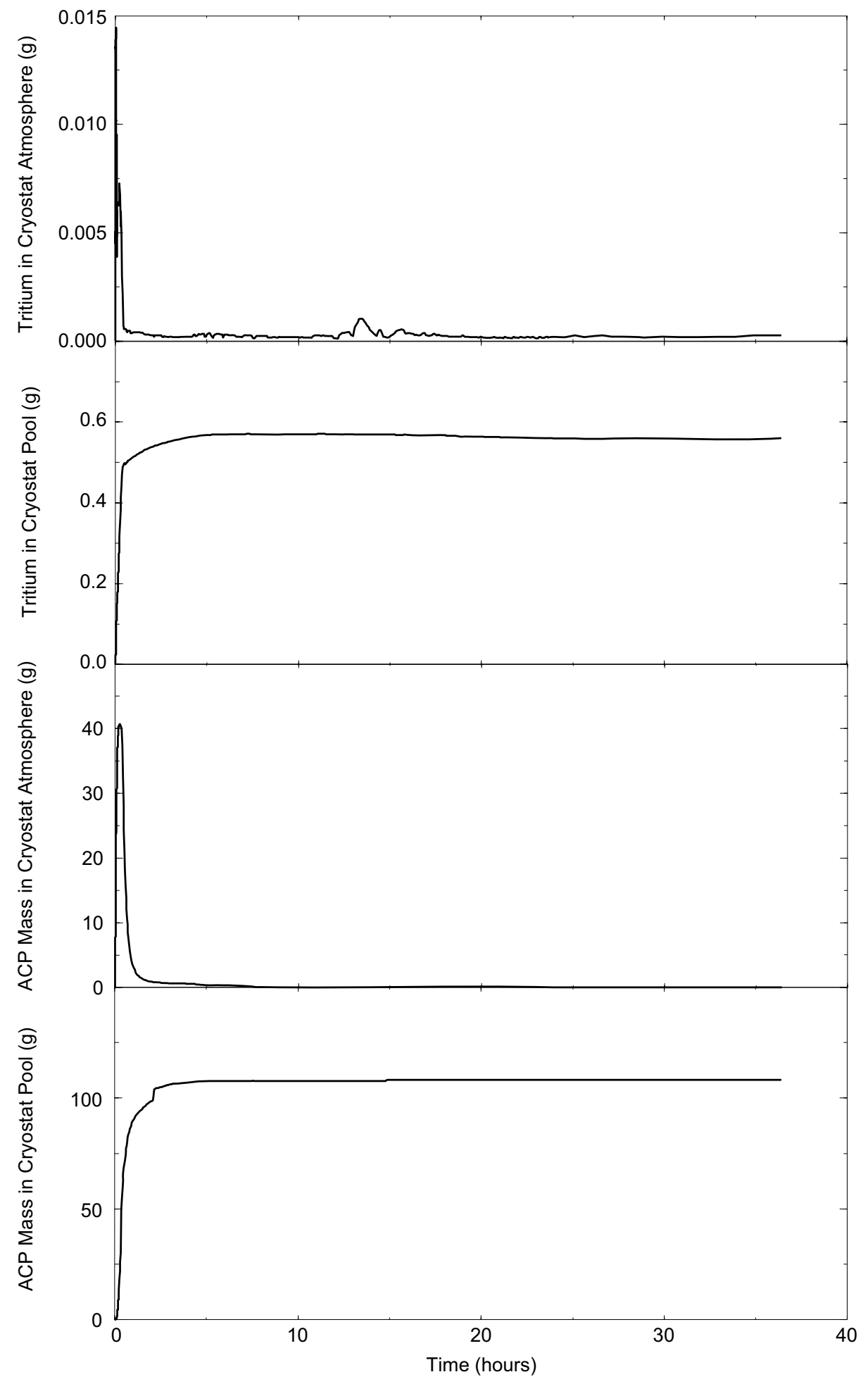

Figure 6. Time Transient of Aerosol Quantities for the Cryostat Water Ingress Event 


\section{Cryostat Water and Helium Ingress Event}

This accident was chosen for consideration in the ITER RPrS as a hypothetical or beyond DBA because a past ITER safety study [GSSR04] demonstrated that this accident could fail the ITER cryostat, which is a secondary confinement boundary of the ITER device. While very little radioactivity is mobilized by this accident, the failure of the cryostat could lead to the mobilization of radioactive material from within the PHTS of ITER into the ITER confinement building and subsequently released to the environment as a result of confinement building pressurization. The following subsections of this report section give the details surrounding this event, the assumptions used to model and analyze this accident, and the predicted consequences to ITER and the radioactive releases to the environment.

\subsection{Identification of Causes and Accident Description}

The anticipated failure of piping from an ITER water cooling system with the maximum coolant enthalpy, which is the first wall/blanket primary heat transport system (FW/BL PHTS) loop, and the simultaneous failure of a line from the helium cryogenic system that contains the maximum inventory of cryogenic helium, which is the toroidal field (TF) coil cooling loop, are postulated to occur inside of the ITER cryostat. The FW/BL PHTS break is postulated to be a double-ended off-set guillotine break of 16 of the largest diameter pipes (ID $=66 \mathrm{~mm}$ ) FW/BL PHTS cooling loop which reside within the ITER cryostat. The pressure difference between the FW/BL PHTS cooling loop ( $3 \mathrm{MPa})$ and the cryostat $\left(10^{-4} \mathrm{~Pa}\right)$ will cause the coolant from this damaged loop to blow down as a steam/water mixture into the cryostat. The breach of a TF coil cooling line is assumed to release $4 \mathrm{~K}$ helium coolant at an initial spill rate of $231 \mathrm{~kg} / \mathrm{s}$ for the first 2.5 seconds, followed by the rate of $60 \mathrm{~kg} / \mathrm{s}$ until the entire helium inventory is lost [Ise00].

Within the cryostat are massive steel structures that operate at cryogenic temperatures ( $4 \mathrm{~K})$, such as the ITER TF coil cases. These structures will condense and freeze the steam being expelled into the cryostat from the damaged FW/BL PHTS loop. As these structures condense this steam, they will increase in temperature. This temperature increase, plus the loss of helium cooling, will cause the superconducting windings of this magnet to undergo a thermal quench. Within seconds of the onset of this quench, the magnet quench protection system will detect the quench and activate the magnet fast discharge system, which will resistively decay the magnet current within the TF coil dump resistors. The temperatures of TF coils rapidly increase to 55K, which is the condition caused by a fast discharge of magnet current. As the magnet current is lost, the magnetic field that confines the ITER plasma will decay, leading to a plasma burn termination and thereby the termination of the direct nuclear heating of the FW/BL structures that are being cooled by the damaged cooling loop. This process is estimated to take place within $30 \mathrm{~s}$ after the initiation of the loop break [AAS07]. No credit is taken for the actuation of the ITER fast plasma termination system (FPTS), which should actuate once the flow within the failed loop drops to $20 \%$ of its normal operating value [SAD07]. However, credit is taken for a safety valve within the TF coil cooling system that will limit the helium release to one-half $(2600 \mathrm{~kg})$ of the total system inventory [AAS07].

The accident is assumed to occur coincident with a 32 hour loss of offsite power. In addition, two aggravating failures are assumed: 1) a two-hour station blackout due to a loss of class-III emergency AC generator power, and 2) the failure of one VV heat transfer loop to switch to a natural convection heat transfer mode [AAS07]. The result will be a loss of forced convection cooling as pumps within the intact FW/BL, divertor, and the vacuum vessel (VV) 
cooling loops coast to a stop in $32 \mathrm{~s}$ after the loss of pump power [SAD07]. The VV cooling loop will transition into the natural convection heat transfer mode upon loss of pumping power and remove the decay heat from the $\mathrm{VV}$ in-vessel components by this heat transfer mode [SAD07]. Table 4-1 lists the sequence of events that have been determined for this accident scenario. Normally the class-III power is available in $30 \mathrm{~s}$. Because some safety systems, such as the PHTS afterheat removal pumps and the VDS, are powered during emergency conditions by class-III power, the loss of this power (a complete station blackout) for an hour is considered to be an aggravating condition for this accident. The consequences of this accident were evaluated for both a normal class-III power startup and a 1 hour delayed class-III power startup. Because there was very little difference in the thermal hydraulic or radiological release results between these scenarios, only the base case with 2 hour station blackout is presented in this report.

The objectives of this accident analysis are to demonstrate that the:

- Accidental overpressure will be safely accommodated by the cryostat (maximum cryostat pressure with safety margin is $180 \mathrm{kPa}$ )

- Show that radioactive releases are adequately confined (radioactive releases are less than ITER accident release limits)

To examine the safety margins or cliff-edge effects associated with this event, an additional parameter study was analyzed for this accident, which is to:

- Consider the total loss of TF coil cooling system helium inventory $(5200 \mathrm{~kg})$ due to the failure of a safety valve in the TF coil cooling line to actuate

Listed below are the safety relevant systems for this accident:

- Cryostat design pressure is $200 \mathrm{kPa}$ ( $2^{\text {nd }}$ radioactive confinement barrier);

- Gallery design pressure is $120 \mathrm{kPa}$ ( $2^{\text {nd }}$ radioactive confinement barrier);

- The gallery HVAC is assumed isolated within 30 seconds after detection of an overpressure of $5 \mathrm{kPa}$

- The leak rate for the gallery is 100 volume $\% /$ day at an over pressure of $300 \mathrm{~Pa}$, and this leak rate scales with the square root of pressure differential.

- The gallery atmosphere is exhausted in normal operation to the environment through the Normal (N)-VDS (dust + ACP filter efficiency $=99.9 \%$, tritium efficiency $=99 \%$ );

- The N-VDS (or safety-ventilation detritiation system S-VDS) will recover the gallery pressure to allow access and maintain the pressure sub-atmospheric.

Table 4-1. Time Sequence of Events for Cryostat Water and Helium Ingress

\begin{tabular}{|l|l|}
\hline Event Sequence & Time \\
\hline Failure of the FW/BL loop and helium cooling loop & $0 \mathrm{~s}$ \\
\hline Maximum break flow rate $(\sim 1245 \mathrm{~kg} / \mathrm{s})$ reached & $\sim 2 \mathrm{~s}$ \\
\hline TF, CS and PF coils discharge & $15 \mathrm{~s}$ \\
\hline Plasma termination & $30 \mathrm{~s}$ \\
\hline Cryostat peak pressure $(200 \mathrm{kPa})$ reached & $\sim 36 \mathrm{~s}$ \\
\hline Gallery peak pressure $(114 \mathrm{kPa})$ reached & $\sim 80 \mathrm{~s}$ \\
\hline Break flow rate drops below $2.5 \mathrm{~kg} / \mathrm{s}$ & $\sim 400 \mathrm{~s}$ \\
\hline Cryostat pressure returns to $100 \mathrm{kPa}$ & $\sim 1000 \mathrm{~s}$ \\
\hline
\end{tabular}




\subsection{Method of Analysis}

A modified version of the MELCOR code was used for this analysis [Moo07a]. The MELCOR code was used to calculate the resulting coolant flow, pressures and temperatures within the cryostat, cryostat space room, gallery and FW/BL-PHTS. MELCOR was also used to calculate structure temperatures of the coil structures and the condensation and freezing of steam on these structures. Table 4-2 lists the major assumptions used in this analysis.

For this accident scenario, the thermal behavior of the TF coils, the gravity supports, the PF coils, CS coils, vacuum vessel (VV), VV thermal shields, cryostat walls, and cryostat thermal shields were simulated. All thermal properties extended down to cryogenic temperatures for this analysis [SAD07]. The MELCOR input deck used for this analysis was that developed by [Top07], which contains a representation of these ITER components, plus the three FW/BL cooling systems and internal VV components, the divertor cooling system and internal VV components, and the VV cooling system and VV walls. Nuclear heating was included for the VV internal components, both during plasma operation and decay heat, plus the surface heating to the VV internal components due to plasma radiant heat and particle losses. While not actuated by this accident scenario, this MELCOR input model contained a representation of the VV pressure suppression system. A detailed description of this model can be found in [Top07]. The input deck used in this study was obtained from the ITER Document Management (IDM) system and had the designation of: CryostatWaterHeIngress 276UVK 3 4.inp. This input deck, with minor revisions identified by [Moo07b], was verified to conform to both the [SAD07] and [AAS07] by [Moo07b].

Table 4-2. Parameters and Initial Conditions for Cryostat Water and Helium Ingress Analysis

\begin{tabular}{|c|c|}
\hline Parameter & Value \\
\hline Break size & FW/BL cooling loop pipe diameter: $66 \mathrm{~mm}$ \\
\hline Coolant temperature of FW/BL PHTS [Tin/Tout] & $100 / 148^{\circ} \mathrm{C}$ \\
\hline FW/BL PHTS coolant inventory/loop & $130 \mathrm{~m}^{3}$ \\
\hline Rate of spilled helium & $231 \mathrm{~kg} / \mathrm{s}$ at $2.5 \mathrm{~seconds}, 60 \mathrm{~kg} / \mathrm{s}$ after that \\
\hline TF coil He inventory & $21 \mathrm{~m}^{3}$ \\
\hline Cryostat volume & $8442 \mathrm{~m}^{3}$ \\
\hline Cryostat leak rate & $1 \%$ volume/day at the design pressure \\
\hline Cryostat condensation area & $\begin{array}{l}8570 \mathrm{~m}^{2}\left(\mathrm{TF} \text { coils }=5230 \mathrm{~m}^{2}, \mathrm{PF} \text { coils }=2450 \mathrm{~m}^{2},\right. \\
\left.\mathrm{CS} \text { coils }=890 \mathrm{~m}^{2}\right)\end{array}$ \\
\hline Mass in cryostat & $\begin{array}{l}9295 \text { tonnes }(\mathrm{TF} \text { coils }=5620 \text { tonnes, } \mathrm{PF} \text { coils }= \\
2750 \text { tonnes, and } \mathrm{CS} \text { coils }=925 \text { tonnes })\end{array}$ \\
\hline Temperatures of structures & TF, PF, CS coils : 55K after discharge \\
\hline Total volume of gallery (plus cryostat space room) & $72,000 \mathrm{~m}^{3}$ \\
\hline Gallery ventilation rate by HVAC & 24 air-volume/day (95\% filter for particles) \\
\hline $\begin{array}{l}\text { Gallery and cryostat space room leak rate through } \\
\text { wall (ground release) }\end{array}$ & $\begin{array}{l}100 \% \text { volume/day } \\
\text { - No leak for sub-atmospheric conditions } \\
\text { - Linear function in the delta P range between }-0.3 \\
\text { and }+0.3 \mathrm{kPa} \text {, beyond this range the leak rate scales } \\
\text { with the square root of the pressure differential }\end{array}$ \\
\hline $\begin{array}{l}\text { Set point for room/HVAC isolation and for } \\
\text { actuating S-VDS }\end{array}$ & $>0.1 \mu \mathrm{g}-\mathrm{T} / \mathrm{m}^{3}$ in room \\
\hline Time delay for room/HVAC isolation & 30 seconds \\
\hline HVAC isolation & Power outage \\
\hline S-VDS processing rate & $\begin{array}{l}3,000 \mathrm{~m}^{3} / \text { hour } \\
\text {-time delay of } 5 \mathrm{~min} \text { for actuation }\end{array}$ \\
\hline S-VDS filtering efficiencies & $99 \%$ for $\mathrm{HTO}, 99.9 \%$ for dust \\
\hline
\end{tabular}




\subsection{Transient Analysis Results for Base Case}

The wave forms shown in Figure 7 for the base case scenario are:

- Cryostat, gallery and FW/BL loop pressures;

- FW/BL break mass flow rate;

- Cryostat vapor and liquid, gallery vapor, and TF magnet surface temperatures;

- Ice mass on magnetic field coil surfaces

The cryostat pressure reaches a maximum value of $200 \mathrm{kPa}$ in $\sim 33$ seconds. At this point, the cryostat is assumed to rupture, relieving this pressurization to the gallery by way of the cryostat space room. The size of this rupture is assumed to be $1 \mathrm{~m}^{2}$ [Top07]. At the time of rupture, the helium partial pressure is $189 \mathrm{kPa}$. Following the rupture, the cryostat pressure drops to near equilibrium with the gallery pressure $(115 \mathrm{kPa})$ at $\sim 80 \mathrm{~s}$. The cryostat and gallery pressures continue to decrease due to leakage from the gallery to the environment, reaching atmospheric pressures by $\sim 1000 \mathrm{~s}$. The break flow drops from a peak of $\sim 1280 \mathrm{~kg} / \mathrm{s}$ to near zero in $400 \mathrm{~s}$. The total amount of water expelled from the FW/BL PHTS into the cryostat during this event is $\sim 109$ tonnes.

The vapor temperature in the cryostat rapidly drops below the triple point temperature of water. The water on the floor of the cryostat takes about 10 hours to completely freeze. In this calculation, these two temperatures are from different MELCOR control volumes within the cryostat model. The vapor is in a volume that is in contact with the magnets and the liquid is in a volume that is in contact with the floor of the cryostat. The TF magnet temperature rises to $55 \mathrm{~K}$ at the start of the accident to simulate the magnet quench, as per specifications in [AAS07]. By 36 hours the surface temperature of these magnets has risen to $\sim 173 \mathrm{~K}$. At this temperature, the magnets are still acting as cryopumps for water vapor. The gallery vapor temperature undergoes a $10 \mathrm{~K}$ decrease during this accident, recovering by $3 \mathrm{~K}$ at 36 hours. The FW surface temperature of the damaged loop experienced a rise in temperature to $510 \mathrm{~K}$ during the period of this event when the cooling water was being lost from this loop and the plasma burn continued. Following plasma termination, this temperature dropped to $373 \mathrm{~K}$ due to internal blanket conduction and then rises to $412 \mathrm{~K}$ as a consequence of decay heating. As can be seen, the decay heat is being effectively removed from the FW/BL by the VV cooling system in its natural convection heat transfer mode.

Ice buildup on the magnets is predicted to continue over the 36 hours analyzed for this accident, as water vapor from water/ice in contact with the cryostat wall continues to evaporate/sublimate. Of the $\sim 109$ tonnes of water discharged from the FW/BL PHTS, approximately $\sim 2.0$ tonnes exists as ice on magnet surfaces by 36 hours. The added weight should be inconsequential to these structures since it represents only an increase of $\sim 0.02 \%$ in total magnet weight. For this event, the presence of a non-condensable gas in the cryostat (helium) greatly reduces the rate of water vapor condensation onto the magnets, as can be seen by comparing this result with that obtained for the cryostat water ingress event (see Section 3).

According to [Mer07], the pedigreed version of MELCOR 1.8.2 under predicts the steam condensation rate for water injection tests in the (EVITA) that also include the co-injection of a non-condensable gas. Assuming that these EVITA tests are prototypical of water and helium ingress accidents in the ITER cryostat, the effect on cryostat pressure of using the recommended 
enhanced steam condensation rate coefficient (e.g., a MELCOR sensitivity coefficient sc4201(1) of 2.5) was investigated for the base case scenario. The wave forms of Figure 8 contains the results of total pressure and steam partial pressure in the cryostat during the first $500 \mathrm{~s}$ of this accident scenario for this enhanced condensation parameter study. As can be seen, the effect on total pressure is small, delaying the cryostat rupture by less than $2 \mathrm{~s}$. The reason for this small effect can be seen in the wave form of cryostat steam partial pressure, where the steam partial pressure is not a significant factor in determining total pressure (e.g., $15 \mathrm{kPa}$ maximum or less than $8 \%$ of the total pressure). So although the maximum steam partial pressure drops by $25 \%$ due to this enhanced condensation case, the total pressure remained relatively unaffected because the dominant factor in determining cryostat pressurization during this accident scenario is the helium gas.

\subsection{Transient Analysis Results for the Parameter Study}

One parameter case was studied for this accident scenario. This parameter study employed the same assumptions and modeling approach as the base case, but assumed that all 21 $\mathrm{m}^{3}(5200 \mathrm{~kg})$ of the TF coil helium coolant inventory would be lost to the cryostat through the damaged cryoline. Wave forms shown in Figure 9 compare the results for this parameter study with those of the base case scenario. These wave forms are:

- Cryostat pressure;

- Gallery pressure;

- Cryostat and gallery break mass flows rate;

- TF magnet surface ice mass

The cryostat pressure reached its maximum value of $200 \mathrm{kPa}$ in $\sim 28$ seconds, which is $5 \mathrm{~s}$ earlier than the base case scenario. At this point, the cryostat is assumed to rupture, relieving this pressurization to the gallery by way of the cryostat space room. The size of this rupture is assumed to be $1 \mathrm{~m}^{2}$. Following the rupture, the cryostat pressure drops to near equilibrium with the gallery pressure $(121 \mathrm{kPa})$ at $\sim 80 \mathrm{~s}$, compared to a time of $\sim 65 \mathrm{~s}$ and a pressure of $115 \mathrm{kPa}$ for the base case scenario. The drop in cryostat pressure for the parameter case at $70 \mathrm{~s}$ coincides with the cessation of helium flow from the damaged cryoline. The pressure in the gallery reaches the design value for this room at $\sim 50 \mathrm{~s}$, at which time the gallery confinement boundary is assumed to fail, resulting in a $1 \mathrm{~m}^{2}$ breach in a gallery wall. Even with this assumed breach, the gallery pressure continues to rise reaching a peak value of $123 \mathrm{kPa}$ at $70 \mathrm{~s}$. Because of the failed gallery wall, the pressures in the cryostat and gallery drop to atmospheric pressure by $\sim 260 \mathrm{~s}$, which did not occur until $1000 \mathrm{~s}$ for the base case. The predicted cryostat and gallery break mass flow rates reach maximum values of $210 \mathrm{~kg} / \mathrm{s}$ and $190 \mathrm{~kg} / \mathrm{s}$ at times of $30 \mathrm{~s}$ and $75 \mathrm{~s}$, respectively.

The FW/BL PHTS break flow rate for the parameter case is virtually identical to that of the base case scenario resulting in the total amount of water expelled from the FW/BL PHTS into the cryostat during this event being $\sim 109$ tonnes. The quantity of ice on the magnets did not vary dramatically from the base case value ( 2.0 tonnes) for this parameter case (1.7 tonnes). The slight decrease in ice buildup is due to the higher non-condensable gas pressure for the parameter case during the initial portion of this accident scenario. In theory, the presence of a non-condensable gas will reduced the condensation rate of the steam onto the magnets. As a consequence, the higher the non-condensable gas pressure the lower the steam condensation rate. However, the predicted ice masses do not represent a structural hazard to the magnets since they are less than $\sim 0.02 \%$ of these magnets' dry weight. 


\subsection{Evaluation of Radiological Release}

In this analysis, the mobilized radioactive materials are tritium, as tritiated water (HTO), and activated corrosion products (ACP) from inside of the failed FW/BL PHTS cooling loop. The maximum tritium concentration of the FW/BL coolant is $0.005 \mathrm{~g}-\mathrm{T} / \mathrm{m}^{3}$ [SAD07]. The fraction of this HTO that is mobilized into the atmosphere of the cryostat is $100 \%$ of the HTO in the steam plus water that spills into the cryostat. Given the fraction of water spilled from the FW/BL PHTS during this event, the amount of tritium mobilized is $\sim 0.63 \mathrm{~g}$-T. The quantity of ACP in a FW/BL PHTS loop is $10 \mathrm{~kg}$ [SAD07]. The fraction of the ACP mobilized into the cryostat atmosphere during this event is $1.3 \%$ of the ACP in the steam plus water inventory spilled [SAD07]. Given the fraction of FW/BL PHTS water spilled during this event, the total mobilized inventory of ACP is $\sim 111 \mathrm{~g}$.

The wave forms shown in Figure 10 are the radiological release results for the base case scenario. These wave forms are:

- Cryostat and gallery tritium mass;

- Tritium leaked from gallery;

- Cryostat and gallery ACP mass;

- ACP leaked from gallery.

Because of the rapid condensation process that occurs in the cryostat during this event, most ( $\sim 99 \%)$ of the mobilized tritium (HTO) resides in the ice/water in the cryostat by 36 hours. It can also be seen that most ( $\sim 85 \%)$ of the mobilized ACP will settle back onto the ice/water pool that forms at the bottom of the cryostat. This leaves about $5 \mathrm{mg}$-T as HTO and $4 \mathrm{~g}$ of ACP that were swept through the cryostat space room and into the gallery by the helium/steam mixture from within the cryostat once the cryostat boundary ruptures. There are two pathways for release of the radioactive material mobilized by this event (the S-VDS system did not actuate since tritium concentration remained below its set point). Both pathways involve release of the material into the cryostat and then flow of gas into the gallery following the breach of the cryostat boundary. Once inside of the gallery, there are two possible mechanisms for release to the environment. The first is by leakage from the gallery to the environment as a result of gallery overpressure. The gallery leakage for the 36 hours analyzed is $0.69 \mathrm{mg}$ and $0.45 \mathrm{~g}$ for the tritium and ACP, respectively. The second is by gallery HVAC flow once the site power is restored and the HVAC system restarts. Figure 10 shows the effect that starting the gallery HVAC has on the mass of aerosol in the cryostat and gallery, which shows a dramatic decay after 32 hours. Table 4-3 summarized the losses by these pathways during the first 36 hours of this event. Since the ITER accidental release limits for tritium as HTO and ACP are $5 \mathrm{~g}$ and $50 \mathrm{~g}$ [How07], respectively, the releases predicted for this event ( $4.3 \mathrm{mg}-\mathrm{T}$ as HTO and $0.50 \mathrm{~g}$ of ACP) are well below ITER limits. 
Table 4-3. Mobilized Inventory, Transport and Release to Environment in Cryostat Water and Helium Ingress

\begin{tabular}{|c|c|c|c|}
\hline $\begin{array}{l}\text { Mobilized } \\
\text { Inventory }\end{array}$ & Release path, transport of inventory & $\begin{array}{l}\text { Release } \\
\text { amount }\end{array}$ & $\begin{array}{l}\text { Total } \\
\text { release }\end{array}$ \\
\hline \multirow[t]{2}{*}{$\begin{array}{l}\text { Tritium in PHTS } \\
\text { loops } \\
0.7 \mathrm{~g}-\mathrm{T}\end{array}$} & $\begin{array}{l}\text { PHTS loops }>>\text { Cryostat }(0.63 \mathrm{~g}-\mathrm{T})>> \\
\text { gallery }\left(5.4 \times 10^{-3} \mathrm{~g}-\mathrm{T}\right)>>\text { HVAC }>> \\
\text { environment }\end{array}$ & $3.6 \times 10^{-3} \mathrm{~g}$ & \multirow{2}{*}{$\begin{array}{l}\text { Tritium: } \\
\text { controlled release } \\
3.6 \times 10^{-3} \mathrm{~g}-\mathrm{T} \\
\text { uncontrolled release } \\
6.9 \times 10^{-4} \mathrm{~g}-\mathrm{T} \\
\text { total release } \\
4.3 \times 10^{-3} \mathrm{~g}-\mathrm{T} \text { as HTO }\end{array}$} \\
\hline & $\begin{array}{l}\text { PHTS loops }>>\text { Cryostat }(0.63 \mathrm{mg}-\mathrm{T})>> \\
\text { gallery }\left(5.4 \times 10^{-3} \mathrm{~g}-\mathrm{T}\right)>>\text { leakage from } \\
\text { the gallery }>>\text { environment }\end{array}$ & $6.9 \times 10^{-4} \mathrm{~g}$ & \\
\hline \multirow[t]{2}{*}{$\begin{array}{l}\text { ACP in one PHTS } \\
\text { loop } \\
10 \mathrm{~kg}\end{array}$} & $\begin{array}{l}\text { PHTS loops }>>\text { Cryostat }(111 \mathrm{~g})>> \\
\text { Gallery }(3.9 \mathrm{~g})>>\text { HVAC }(95 \% \text { filtering }) \\
>>\text { environment }\end{array}$ & $5.2 \times 10^{-2} \mathrm{~g}$ & \multirow{2}{*}{$\begin{array}{l}\text { ACP: } \\
\text { controlled release } \\
5.2 \times 10^{-2} \mathrm{~g} \\
\text { uncontrolled release } \\
4.5 \times 10^{-1} \mathrm{~g} \\
\text { total release } \\
5.0 \times 10^{-1} \mathrm{~g}\end{array}$} \\
\hline & $\begin{array}{l}\text { PHTS loops }>>\text { Cryostat }(111 \mathrm{~g})>> \\
\text { Gallery }(3.9 \mathrm{~g})>>\text { leakage from the } \\
\text { gallery }>>\text { environment }\end{array}$ & $4.5 \times 10^{-1} \mathrm{~g}$ & \\
\hline
\end{tabular}

\subsection{Evaluation of Parameter Study Radiological Release}

Because the cryostat and gallery pressures are higher for the parameter case than the base case, more ACP mass was transported from the cryostat to the gallery and once in the gallery this ACP mass is leaked to the environment. The mass of tritium and ACP swept into the gallery for this accident are $8.2 \times 10^{-3} \mathrm{~g}-\mathrm{T}$ (as HTO) and $10.4 \mathrm{~g}$ of ACP, compared to $5.4 \times 10^{-3} \mathrm{~g}-\mathrm{T}$ (as HTO) and $3.9 \mathrm{~g}$ of ACP for the base case. The mass of tritium and ACP leaked from the gallery was $5.9 \times 10^{-3} \mathrm{~g}-\mathrm{T}$ (as HTO) and $4.7 \mathrm{~g}$ of ACP, compared to $6.9 \times 10^{-4} \mathrm{~g}-\mathrm{T}$ (as HTO) and $0.45 \mathrm{~g}$ of ACP for the base case, which is reasonable given the failure of the gallery confinement boundary in the parameter case. Because less tritium and ACP mass exists in the gallery at the time the HVAC system restarts, due to a higher leakage in the parameter case, the loss of tritium and ACP to the environment once the HVAC system restarts is lower for the parameter case at $1.5 \times 10^{-3} \mathrm{~g}-\mathrm{T}$ (as HTO) and $1.5 \times 10^{-2} \mathrm{~g}$ of ACP, compared to $3.6 \times 10^{-3} \mathrm{~g}-\mathrm{T}$ (as HTO) and $5.2 \times 10^{-2} \mathrm{~g}$ of ACP for the base case.

The total release to the environment predicted for the parameter case is $7.4 \times 10^{-3} \mathrm{~g}-\mathrm{T}$ (as HTO) and $4.7 \mathrm{~g}$ of ACP, compared to $4.3 \times 10^{-3} \mathrm{~g}$-T (as HTO) and $0.5 \mathrm{~g}$ of ACP for the base case scenario. While there was a factor of $\sim 9$ increase in the ACP release, the releases are still well below the release limits for ITER of $5 \mathrm{~g}$-T (as HTO) and $50 \mathrm{~g}$ of ACP, demonstrating no cliffedge effect for this parameter case.

\subsection{Uncertainties in Results}

There is some uncertainty regarding these analyses that is due to the simplistic modeling of radioactive source terms, and the level of detail used to model the ITER cryostat. In the analyses, conservative assumptions are used such that more detailed modeling should not result in higher releases, for example the assumption regarding mobilization of radioactivity. In addition, these radioactive source terms (FW/BL-PHTS tritium and ACP) will be controlled by operational 
procedures, in which case all of the tritium could be released and a confinement factor of only $\sim 3$ would be required for the mobilized ACP to remain below ITER release limits.

There is also some uncertainty regarding the MELCOR code's ability to accurate predict cryostat pressure for this event. However, based on validation studies presented in [Top01] and [Sar06], the MELCOR code is capable of correctly predicting pressures for these conditions, provided that attention is given to providing this code with adequate modeling details of the ITER device.

\subsection{Summary}

The postulated breach of 16 of the largest diameter pipes (ID $=66 \mathrm{~mm})$ of a FW/BL PHTS cooling loop that reside within the ITER cryostat, and the simultaneous breach of a cryogenic system cooling line for a TF magnet was analyzed. The calculated pressure in the cryostat reached the cryostat design limit within $33 \mathrm{~s}$, resulting in a rupture of this boundary and mass flow from the cryostat into the gallery by way of the cryostat space room. The maximum predicted gallery pressure was only $115 \mathrm{kPa}$.

The mass of tritium and ACP mobilized during this event was $0.63 \mathrm{~g}-\mathrm{T}$ and $111 \mathrm{~g}$, respectively. Based on this mobilized mass, the predicted release to the environment is $4.3 \times 10^{-3}$ $\mathrm{g}$-T (as HTO) and $0.50 \mathrm{~g}$ of ACP for this event scenario, which are well below ITER Accident Release Limits. 


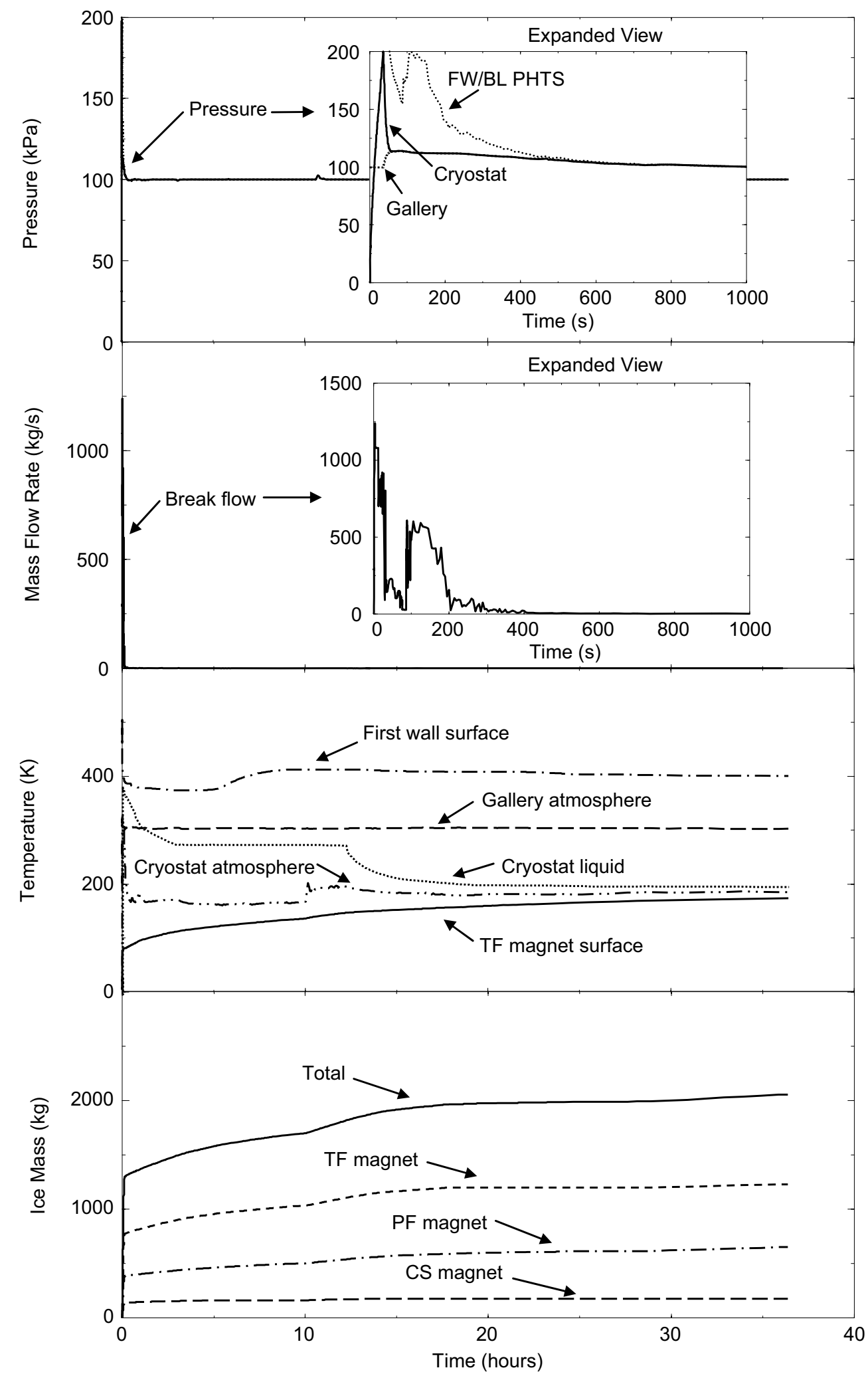

Figure 7. Time Transient of Physical Quantities for the Cryostat Water Helium Ingress Event 


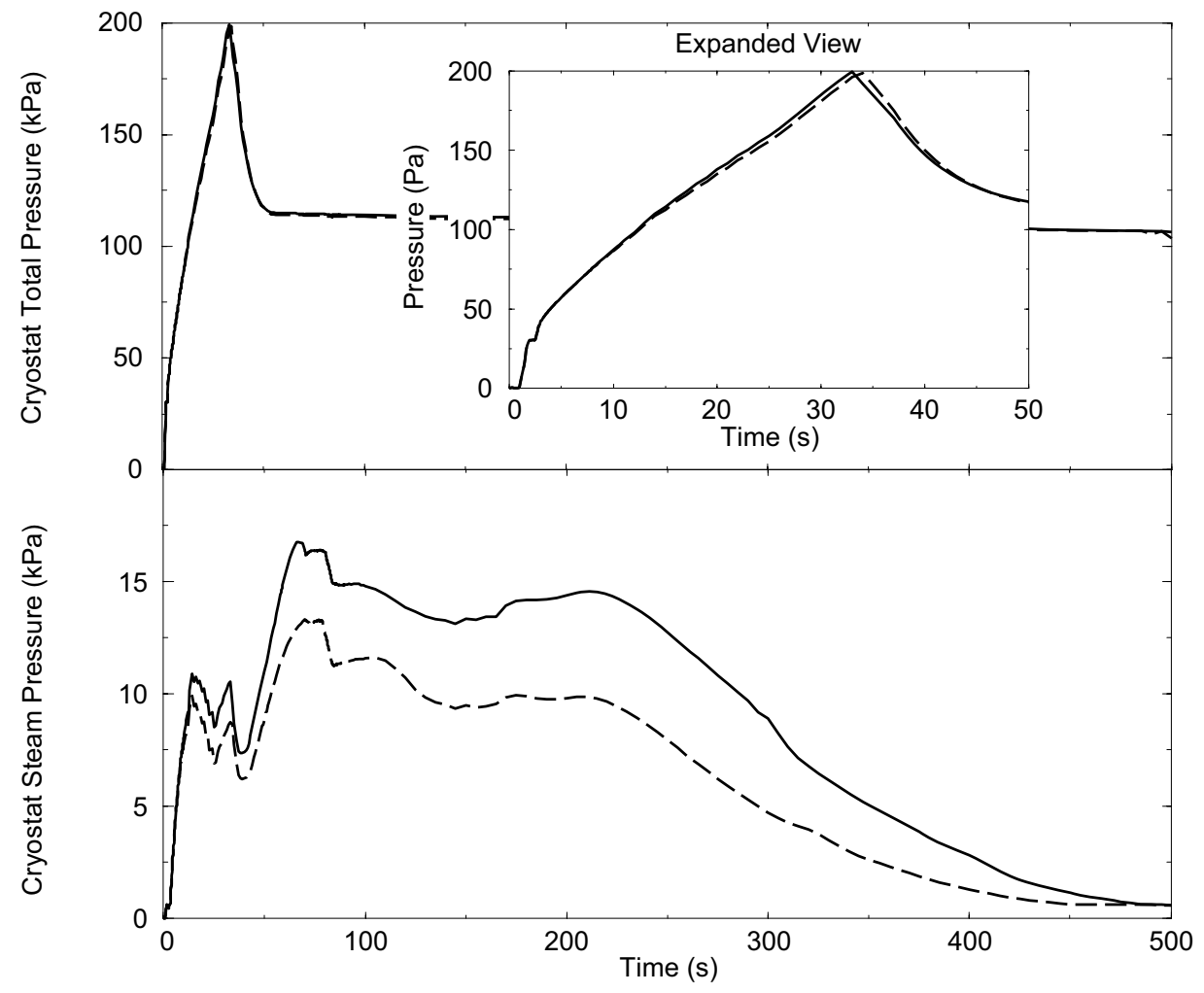

Figure 8. Time Transient of Cryostat Pressures for the Cryostat Water Helium Ingress Event When Enhanced Steam Condensation is Considered 


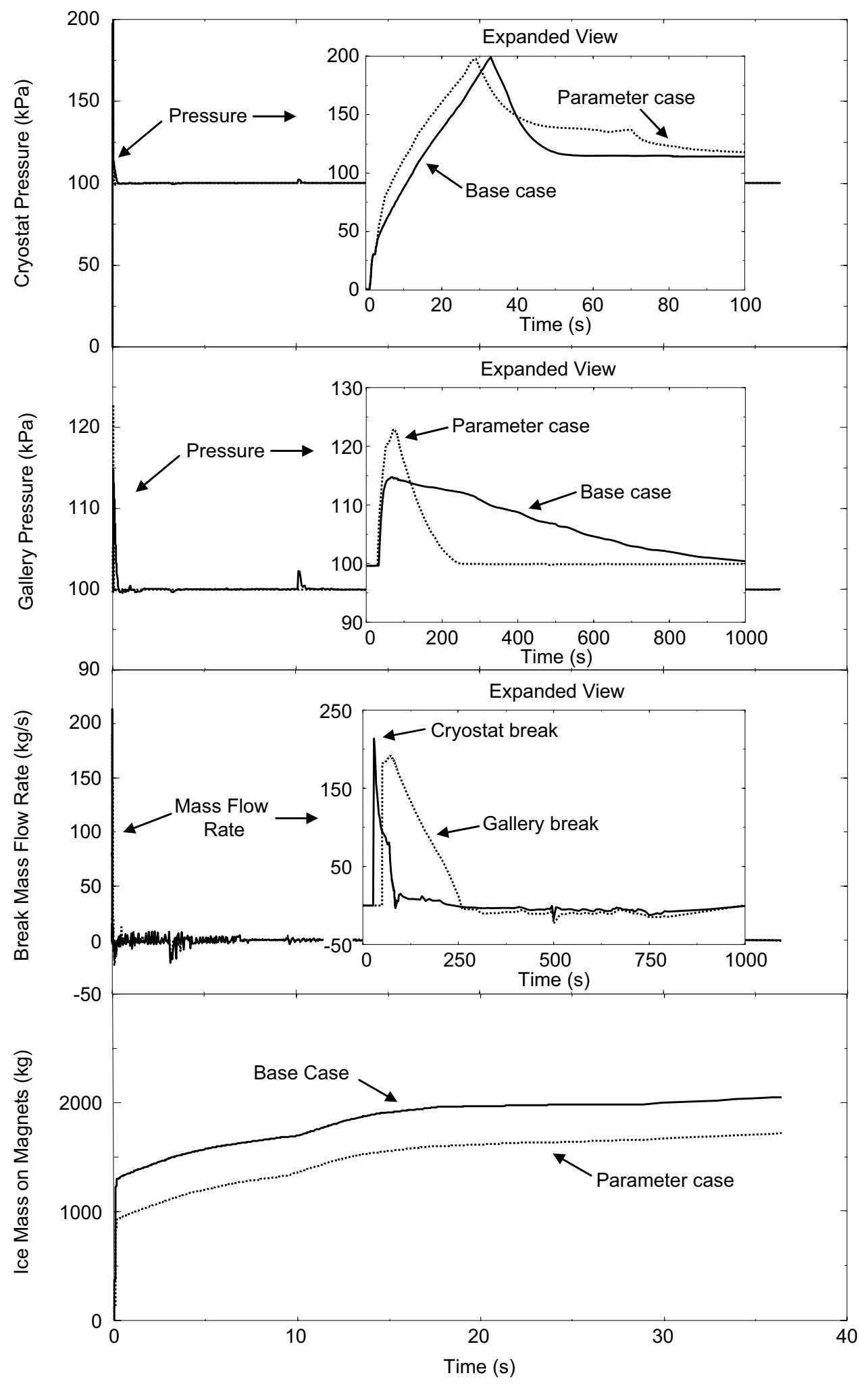

Figure 9. Time Transient of Physical Quantities for the Parameter Study for the Cryostat Water Helium Ingress Event 


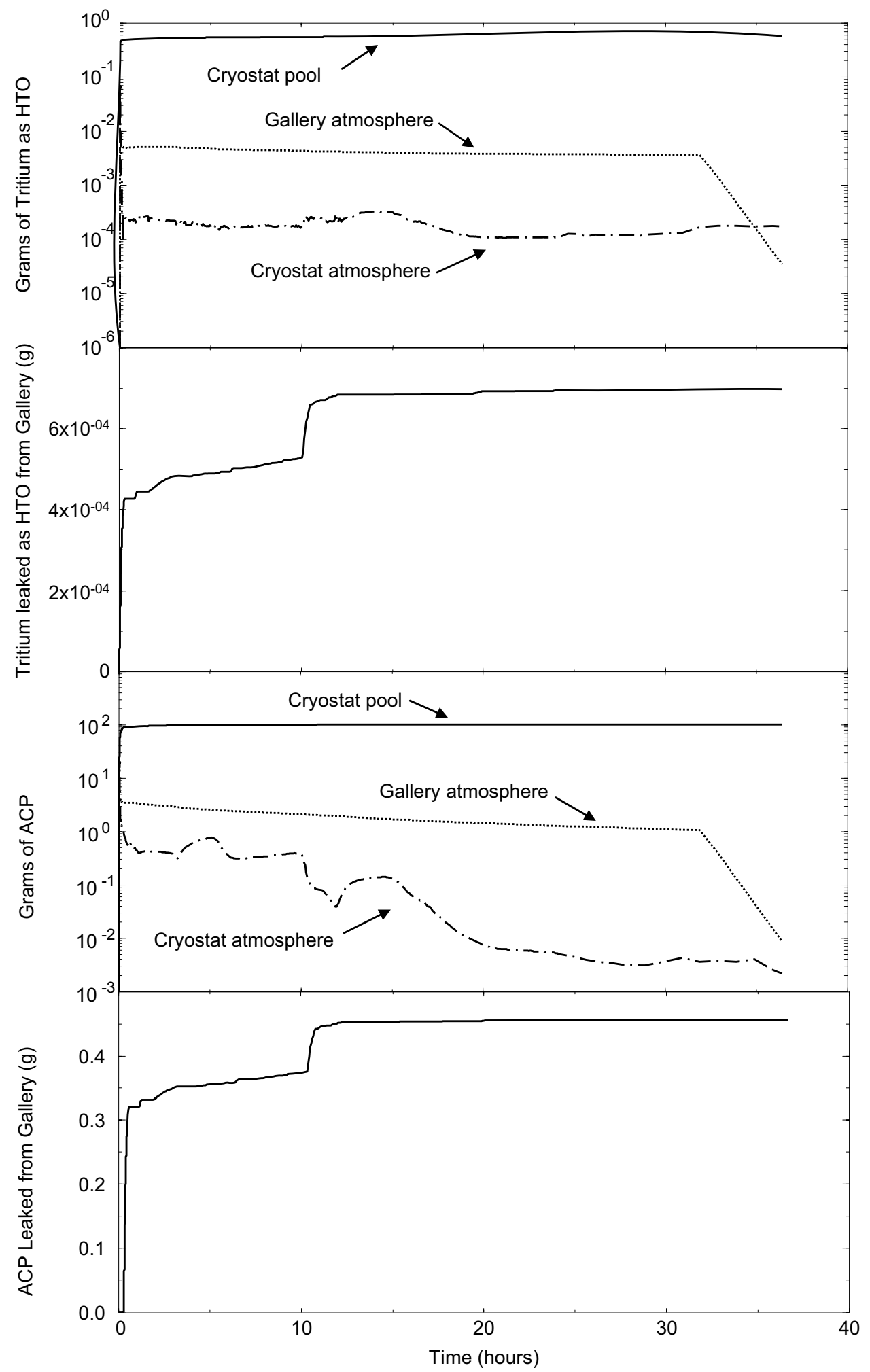

Figure 10. Time Transient of Radioactive Quantities for the Cryostat Water Helium Ingress Event 


\section{REFERENCES}

[AAS07] Reyes, S., et al., “Accident Analysis Specifications (AAS),” ITER Document, ITER D 258QGE, v2.5, August (2007).

[GSSR04] “Generic Site Safety Report,” ITER Report, ITER G 84 RI 6 R0.2, July (2004).

[How07] How, J., “Project Integration Document: PID," ITER Document, ITER D 2234RH, v3.0, January (2007), pg 47.

[Ise00] Iseli, M., "Short Term Cryostat Pressurization by Water and Helium Ingress", ITER Naka JCT, N24 MD5 00-10-03 W0.1, 03 October 2000.

[Mer07] Merrill, B. J., "Benchmarking MELCOR 1.8.2 for ITER Against Recent EVITA Results," Idaho National Laboratory Report, INL/EXT-07-13521, December (2007).

[Moo07a] Moore, R. L., "Pedigree Analysis of the MELCOR 1.8.2 Code to be Used for ITER's Report Preliminary on Safety," Idaho National Laboratory Report, INL/EXT-0712856, June (2007).

[Moo07b] Moore, R. L., "Verification of MELCOR Input Decks Used in ITER RPrS Analyses," Idaho National Laboratory Report, INL/EXT-07-13305, to be published.

[SAD07] Topilski, L., et al., "Safety Analysis Data List," ITER Report, ITER D 24LSAE, version 5.2, May 29 (2007).

[Sar06] Sardain, P., et al., "Validation of thermal hydraulic codes for fusion reactors safety," (Proceedings of $24^{\text {th }}$ Symposium on Fusion Technology), Warsaw Poland, September $11^{\text {th }}-15^{\text {th }}, 2006$.

[Sau07] N. Sauthoff, "Support and assistance for MELCOR Quality Assurance and Safety Analyses,” ITER Task Agreement, ITA 81-18, TN C81TD30FU, June 3 (2007).

[TAY03] Taylor, N. P.., et al., "ITER at Cadarache: An example of licensing a fusion facility," Fusion Science and Technology, 44(2003) 251-255.

[Top01] Topilski, L. N., et al., "Validation and benchmarking in support of ITER-FEAT safety analysis," Fusion Engineering and Design 54 (2001) 627-633.

[Top07] Topilski, L. N., “Thermal-hydraulic Models Used for the ITER Safety Analysis," ITER Document, IDM D 277XZG, v1.0, June (2007). 